\title{
Mechanism of the 1975 Kalapana, Hawaii, earthquake inferred from tsunami data
}

\author{
Kuo-Fong Ma \\ Institute of Geophysics, National Central University, Chung-Li, Taiwan \\ Hiroo Kanamori \\ Seismological Laboratory, California Institute of Technology, Pasadena
}

Kenji Satake

Seismotectonics Section, Geological Survey of Japan, Tsukuba, Japan

\begin{abstract}
We investigated the source mechanism of the 1975 Kalapana, Hawaii, earthquake $\left(M_{S}=7.2\right)$ by modeling the tsunamis observed at three tide-gauge stations, Hilo, Kahului, and Honolulu. We computed synthetic tsunamis for various fault models. The arrival times and the amplitudes of the synthetic tsunamis computed for Ando's fault model (fault length $=40 \mathrm{~km}$, fault width $=20 \mathrm{~km}$, strike $=\mathrm{N} 70^{\circ} \mathrm{E}, \mathrm{dip}=20^{\circ} \mathrm{SE}$, rake $=-90^{\circ}$, fault depth $=10 \mathrm{~km}$, and slip $=5.6 \mathrm{~m}$ ) are $\sim 10$ min earlier and 5 times smaller than those of the observed, respectively. We tested fault models with different dip angles and depths. Models with a northwest dip direction yield larger tsunami amplitudes than those with a southeast dip direction. Models with shallower fault depths produce later first arrivals than deeper models. We also considered the effects of the Hilina fault system, but its contribution to tsunami excitation is insignificant. This suggests that another mechanism is required to explain the tsunamis. One plausible model is a propagating slump model with a $1 \mathrm{~m}$ subsidence along the coast and a $1 \mathrm{~m}$ uplift offshore. This model can explain the arrival times and the amplitudes of the observed tsunamis satisfactorily. An alternative model is a wider fault model that dips $10^{\circ} \mathrm{NW}$, with its fault plane extending $25 \mathrm{~km}$ offshore, well beyond the aftershock area of the Kalapana earthquake. These two models produce a similar uplift pattern offshore and, kinematically, are indistinguishable as far as tsunami excitation is concerned. The total volume of displaced water is estimated to be $\sim 2.5 \mathrm{~km}^{3}$. From the comparison of slump model and the single-force model suggested earlier from seismological data we prefer a combination of faulting and large-scale slumping on the south flank of Kilauea volcano as the most appropriate model for the 1975 Kalapana earthquake. Two basic mechanisms have been presented for explaining the deformation of the south flank of Kilauea: (1) pressure and density variation along the rift zone caused by magma injection and (2) gravitational instability due to the steep topography of the south flank of Kilauea. In either mechanism, large displacements on the south flank are involved that are responsible for the observed large tsunamis.
\end{abstract}

\section{Introduction}

The 1975 Kalapana, Hawaii, earthquake $\left(M_{S}=7.2\right)$ is the largest Hawaiian earthquake instrumentally recorded. It occurred at 04 47:30 Hawaiian Standard Time (14 47:30 gmt) on November 29, 1975 [Tilling et al., 1976], and the location given by Hawaiian Volcano Observatory (HVO) is at $19^{\circ} 20^{\prime} \mathrm{N}$, $155^{\circ} 02^{\prime} \mathrm{W}$ and a depth of $5-7 \mathrm{~km}$ (Figure 1a). This earthquake affected most of the south flank of Kilauea volcano between the southwest rift zone and the east rift zone (Figure $\mathrm{lb}$ ) and was accompanied by large tsunamis that caused significant damage. The tsunamis were observed at several locations along the coast. A severe tsunami reached a maximum height of $14.6 \mathrm{~m}$ at Halape beach (Figure 1b), where two campers were killed. Similar large earthquakes accompanied by tsunamis previously occurred in this region of the island in 1868 and 1823.

Copyright 1999 by the American Geophysical Union.

Paper number 1999JB900073.

0148-0227/99/1999JB900073\$09.00
Several studies have been made to determine the mechanism of the 1975 Kalapana earthquake using seismic, aftershock. geodetic, and tsunami data. From the analysis of seismic waves, tsunami, and crustal deformation data, Ando [1979] obtained anormal-fault mechanism for this earthquake with strike $=\mathrm{N} 70^{\circ} \mathrm{E}$ : dip $=20^{\circ} \mathrm{SE} ;$ fault length $=40 \mathrm{~km}$; width $=20-30 \mathrm{~km}$; depth $=10$ $\mathrm{km}$; slip $=5.5-3.7 \mathrm{~m}$. Furumoto and Kovach [1979], using teleseismic and local seismic data, obtained an overthrust mechanism with a dip of $4^{\circ} \mathrm{NW}$ and a strike of $\mathrm{N} 64^{\circ} \mathrm{E}$. These solutions are shown in Figure 1c. Crosson and Endo [1982] made extensive studies of south flank earthquakes, suggested a decoupling layer that is the old oceanic sediment layer at the base of the volcanic pile on the south flank of Kilauea, and proposed a mechanical model for south flank deformation that involves slip motion occurring on top of the old oceanic crust. These seismological studies suggested that the Kalapana earthquake occurred on a nearly horizontal fault piane at a depth of $7-9 \mathrm{~km}$, although the dip angle of this plane differed among different investigators. Wyss and Kovach [1988] argued for a nearly horizonta! thrust faulting mechanism with secondary normal 
a

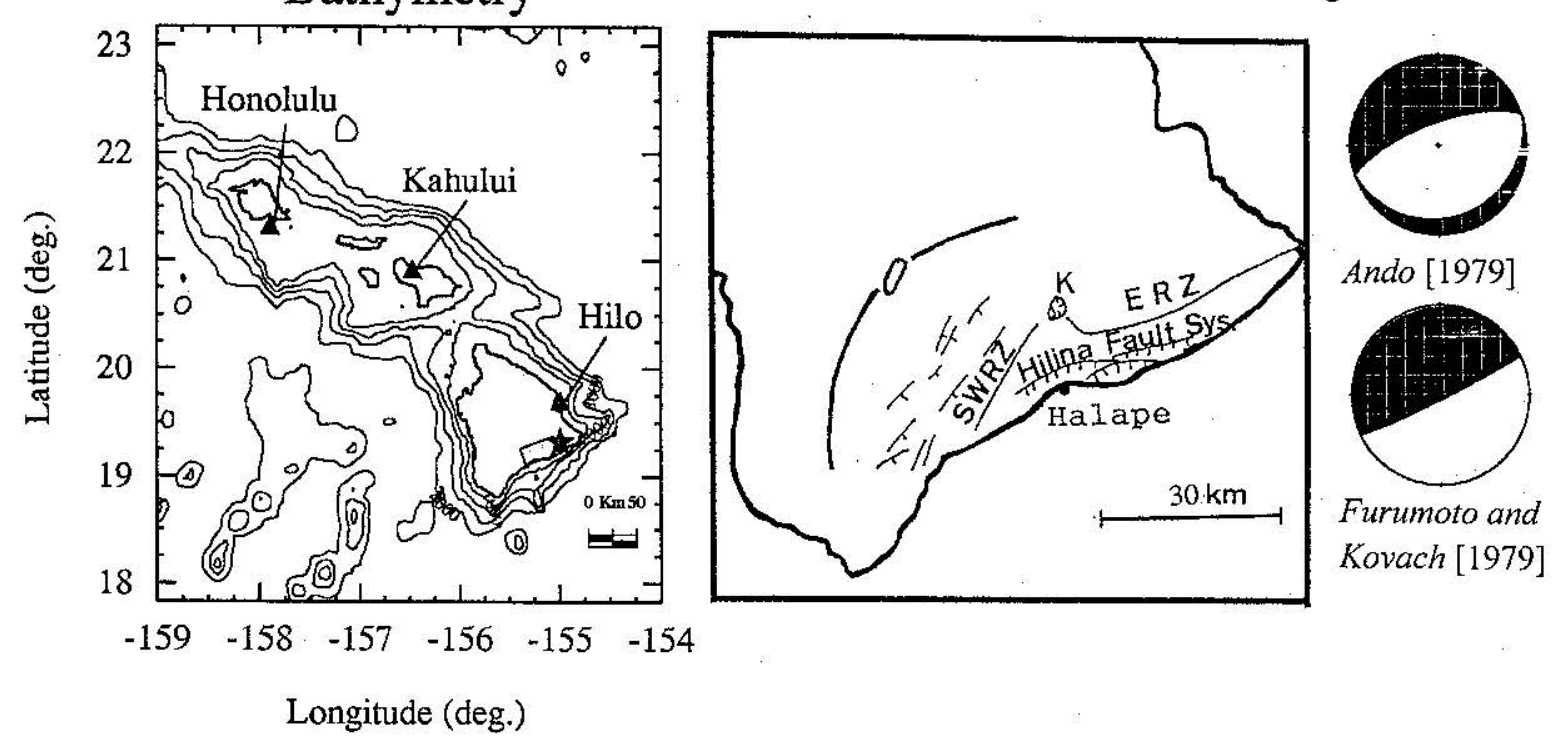

Figure 1. (a) The epicenter (star) and the faut plane of the 1975 Kalapana earthquake and three tide-gauge stations (triangle). The bathymetry around the Hawaiian Islands is shown by contour lines with intervals of 1000 m. (b) Kilauea (K), east rift zone (ERZ), southwest rift zone (SWRZ), and the Hilina fault system. (c) The focal mechanism (equal-area projection of the lower focal hemisphere) of the 1975 Kalapana earthquake determined by Ando [1979] and Furumoto and Kovach [1979]. The shaded and open areas represent compression and dilatation, respectively.

faulting that may have involved gravitational slumping. More recently, Bryan and Johnson [1991] analyzed the mechanisms of earthquakes on the island of Hawaii from 1986 to 1989 and suggested that Kilauea's south flank is mobile and moving seaward.

The vertical displacement associated with the 1975 Kalapana earthquake was reported by Lipman et al. [1985] (Figure 2). The maximum displacement occurred at Halape with subsidence of $3.5 \mathrm{~m}$. The amount of subsidence along the south flank of Kilauea decreases abruptly to the west of Halape and more gradually to the east. The horizontal extensions observed by Lipman et al. [1985] show a steadily increasing trend seaward

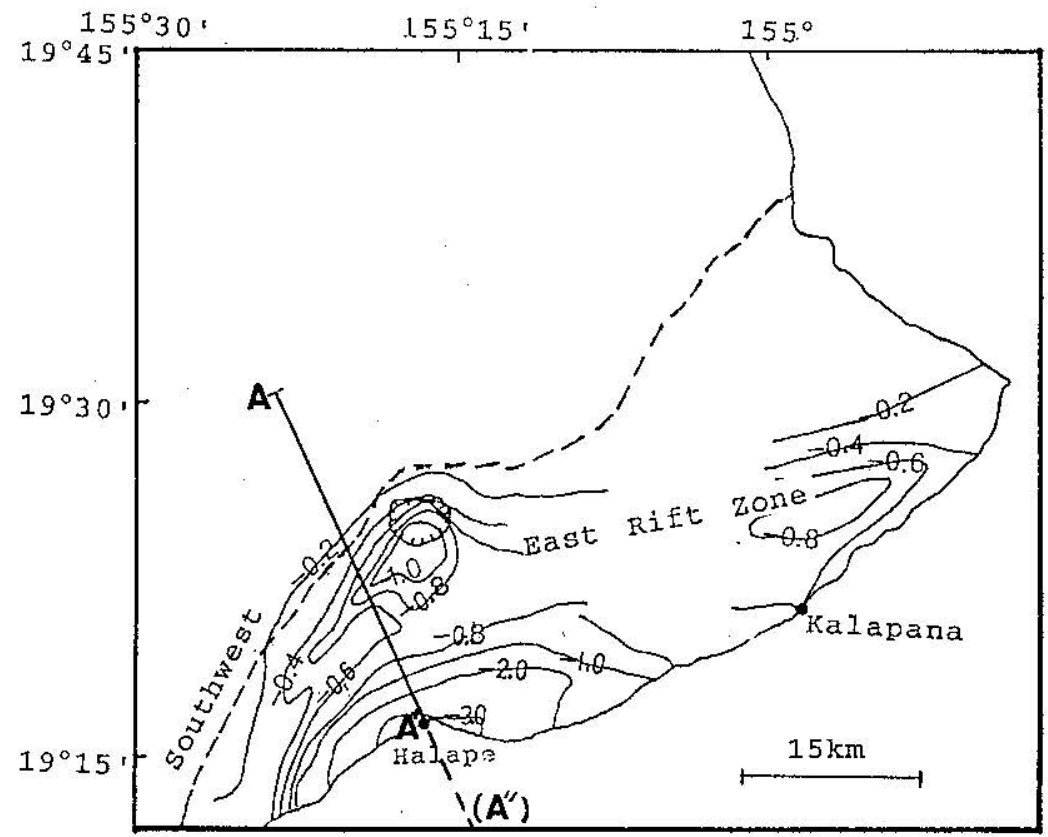

Figure 2. The vertical displacement associated with the 1975 Kalapana earthquake [after Lipman et al. 1985] and the cross section line $\mathrm{AA}^{\prime}$. The contour lines indicate the uplift (positive) and subsidence (negative) in meters (simplified from Lipman et al. |1985]). A'A" extends the cross-section line of $\mathrm{AA}^{\prime}$ to offshore with the same distance. 
over the south flank (Figure 3) and ground cracks along the 25 $\mathrm{km}$ of the Hilina fault system. The subaerial horizontal displacement increased from $1 \mathrm{~m}$ near the summit of Kilauea to 8 $m$ at the coast. The maximum horizontal displacement occurred in the same area of the south flank as the maximum subsidence. Considering the average subsidence and seaward displacement, they estimated that the total volume of deformation is $\sim 2 \mathrm{~km}^{3}$. Swanson et al. [1976] noted that the entire south flank of Kilauea is mobile and has undergone extensions of several meters in the century prior to the 1975 Kalapana earthquake. More recently, Owen et al. [1995] concluded from Global Positioning System (GPS) measurements that the rapid deformation of the south flank can be explained by slip on a low-angle fault beneath the south flank combined with dilation deep within the Kilauea's rift system.

Swanson et al. [1976], Dvorak et al. [1986, 1994], and Dvorak [1994] proposed that the magina system beneath Kilauea volcanoes must have pushed the south flank seaward. Denlinger and Okubo [1995] considered the geological structure, seismicity, and deformation of the south flank of Kilauea and suggested that the structure of the mobile south flank is probably associated with a magma system at a depth below $4 \mathrm{~km}$, which pushes a wedgeshaped portion of the south flank seaward on the decollement. The decollement begins with the 7 to $10 \mathrm{~km}$ deep band of seismicity bordering the east rift zone and Koae fault system. They suggested the association of a localized offshore topographic bench, $30-50 \mathrm{~km}$ from shore and $5 \mathrm{~km}$ below sea level, with the decollement structure. They also suggested that the magma pressure in the wedge-shaped portion of south flank of Kilauea is an important driving mechanism of the slump on the decollement. This result suggests that the slumping induced by the magma intrusion is the most important factor for producing large tsunamis. According to this result, if the soth flank fails in a more catastrophic landslide, it will yield even larger tsunamis than those generated by the 1975 Kalapana earthquake.

The 1975 Kalapana earthquake exhibited a somewhat peculiar radiation of long-period surface waves. On the basis of the radiation pattern of Love waves, Eissler and Kanamori [1987] proposed a near-horizontal single-force mechanism that represents slumping. The single force is oriented opposite to the direction of the inferred slumpirig on the south flank of Kilauea volcano. However, Kawakatsu [1989] showed that the overall radiation patterns of fundamental and overtone surface waves can be explained with a fault model (i.e., double couple).

Now it is generally agreed that the 1975 Kalapana earthquake involved large horizontal displacement on a nearly horizontal decollement at a depth of $7-9 \mathrm{~km}$ on the south flank of Kilauea. However, the extent, the magnitude, and the timescale of the displacement offshore are still uncertain because of the lack of geodetic data. It is essential to understand the nature of the deformation field offshore for a better understanding of the mechanism of deformation of the south flank of Kilauea. In this paper we model the Isunami data observed in Hawail to gain further constraints on the mechanism of this earthquake. The tsunamis excited by this earthquake were well recorded at several tide-gauge stations around the Hawaiian Islands. Tsunami data provide useful constraints on crustal deformation in the offshore area and complement the geodetic data, which are limited to onshore areas.

We will show that an average vertical displacement of $\sim 1 \mathrm{~m}$ over an offshore area of $\sim 2800 \mathrm{~km}^{2}$ is necessary to explain the tsunamis. This uplift can be most easily explained by a largescale seaward extension of the horizontal slip on the onshore decollement.

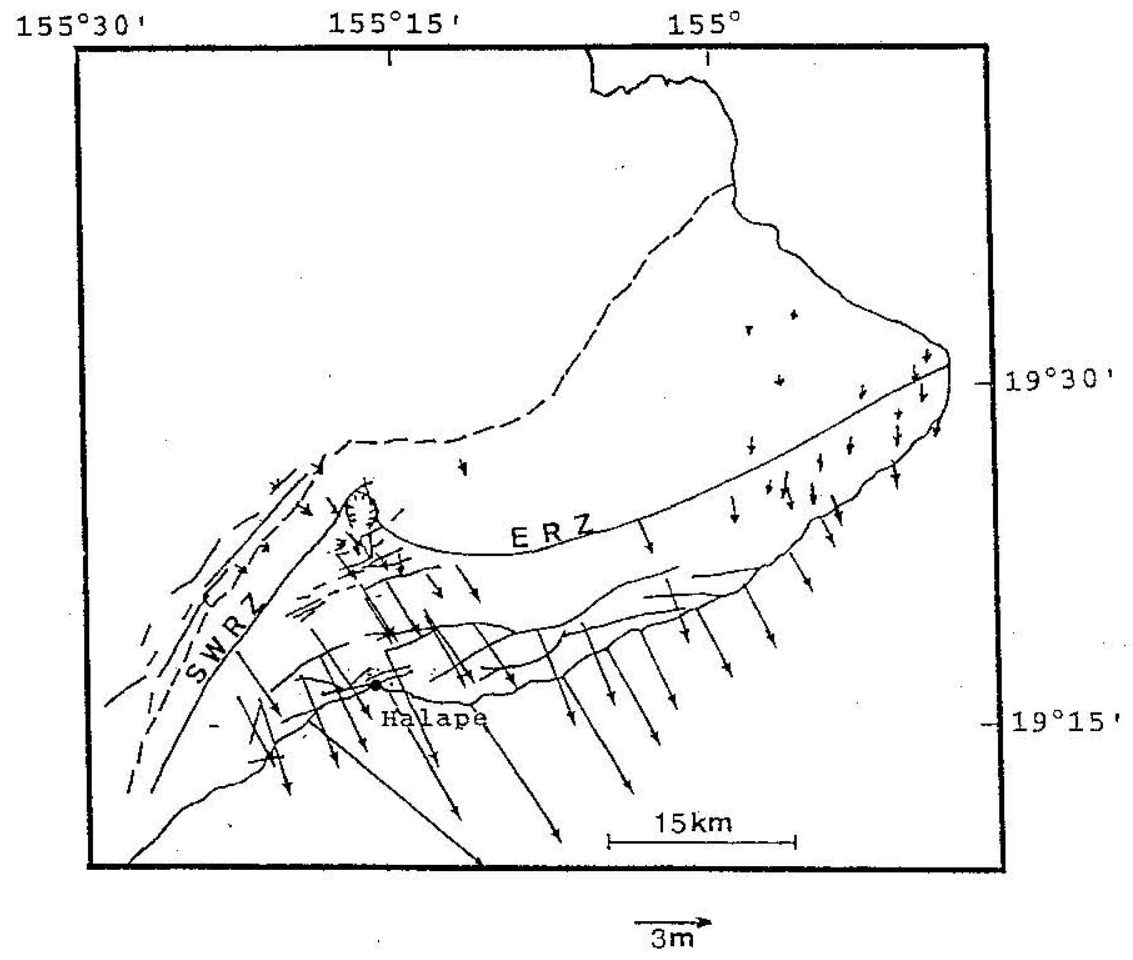

Figure 3. The horizontal displacement associated with the $1975 \mathrm{Kalapana}$ earthquake (simplified from Lipman et al. $[1985])$. 


\section{Tsunami}

Tsunamis from the 1975 Kalapana earthquake have been studied by several investigators. Hatori $[1976]$, using a tsunami ray-tracing method, estimated the possible tsunami-generating area to be $2200 \mathrm{~km}^{2}$ where an average uplift of $1 \mathrm{~m}$ occurred. Ando [1979] computed a synthetic tsunami at Hilo tide station for his seismic fault model. His synthetics have amplitudes too small compared with the observed amplitudes. Here we investigate the three tide gauge records observed at Hilo, Honolulu, and Kahului (Figure 1a) to determine the seafloor deformation that is responsible for the tsunamis and the possible mechanism of the 1975 Kalapana earthquake.

\subsection{Data}

Figure 4a shows the tsunami records at three tide gauge stations. Hilo, Honolulu, and Kahului, taken from Cox [1980]. According to the gauge-time corrections determined by Cox [1980] by checking the clocks on the day before and after the earthquake the average timing errors were $0,-0.5$, and $6.5 \mathrm{~min}$ for Hilo, Honolulu, and Kahului, respectively. The positive and negative signs indicate the advance and delay of the tide-gauge clocks, respectively. Applying the gauge-time corrections to the tide-gauge records, we digitized the records for 1.5 hours starting from the origin time of the earthquake and detrended them. Figure $4 \mathrm{~b}$ shows the time-corrected detrended records. Although the records show some background noise, we can identify the distinct upward first arrivals as indicated on Figure 4b. The first arrivals thus identified at Hilo. Honolulu, and Kahului are at 23,48 , and $49 \mathrm{~min}$ after the origin time of the earthquake, respectively, with an error of $\sim 2 \mathrm{~min}$. The peak to peak amplitudes are $-180,15$, and $85 \mathrm{~cm}$ at Hilo, Honolulu, and Kahului, respectively.

\subsection{Method}

Tsunami modeling has been done by many investigators. For example, Aida [1969] performed numerical modeling to study tsunamis caused by the 1964 Niigata and 1968 Tokachi-Oki earthquakes. The computed tsunami waveforms were in satisfactory agreement with those observed at tide-gauge stations. Hwang et al. $\quad[1970,1972 \mathrm{a}, \mathrm{b}]$ simulated the tsunamis caused by the 1964 Alaskan, the 1960 Chilean, and the 1957 Andreanof Islands earthquakes. They developed a numerical model for generation and transoceanic propagation of tsunamis using hydrodynamic equations in a spherical coordinate system. Aida [1978] showed that most tsunamis can be approximately explained with seismic fault models. Recent studies by Satake [1987, 1989] showed that the slip distribution on the fault plane of large submarine earthquakes can be determined by inversion of tsunami waveforms. Ma et al. [199la, b] determined the vertical seafloor deformation associated with the 1989 Loma Prieta, California, and the 1906 San Francisco, California, earthquakes from tsunami data obtained at nearby tide-gauge stations. Recently, the tsunami modeling technique has been extensively applied to determine the space and temporal variations of slip of important tsunamigenic and tsunami earthquakes [Johnson and Satake, 1996; Tanioka and Satake, 1996: Johnson and Satake, 1997]. A useful review of this subject is given by Geist [1997].

We take a Cartesian coordinate system $(x, y, z)$ with the $z$ axis oriented vertically. Then the basic equations of motion for tsunami computation are given by

$$
\frac{\partial u}{\partial t}+u \frac{\partial u}{\partial x}+v \frac{\partial t}{\partial y}-f v=-g \frac{\partial H}{\partial x}-\frac{r u\left(u^{2}+v^{2}\right)^{1 / 2}}{(H+D-\eta)}
$$

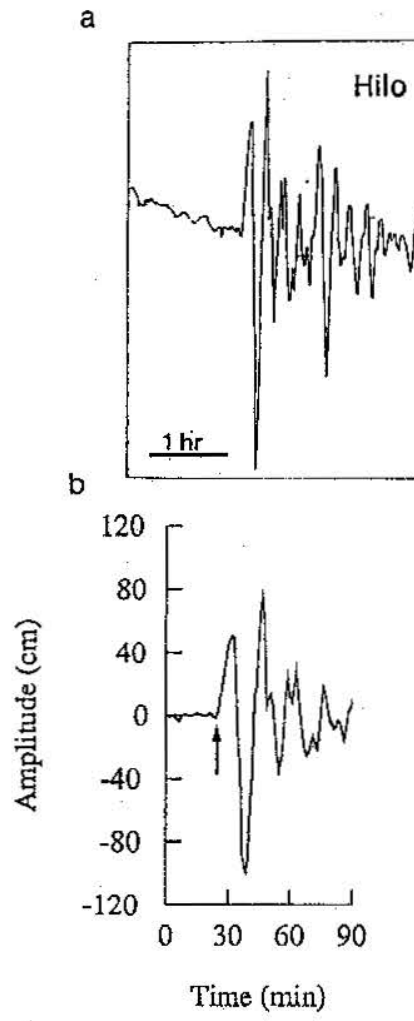

Figure 4. (a) Tsunamis recorded on the tide gauges at Hilo, Honolulu, and Kabului. records for $90 \mathrm{~min}$ starting from the origin time. Arrows indicate the onset of tsunami.

(b) Detrended tsunami 


$$
\frac{\partial}{\partial}+u \frac{\partial}{\partial x}+v \frac{\partial}{\partial y}+f u=-g \frac{\partial H}{\partial y}-\frac{r u\left(u^{2}+v^{2}\right)^{1 / 2}}{(H+D-\eta)}
$$

where $u$ and $v$ are the $x$ and $y$ components of velocity, $H$ is the water level relative to still water, $f$ is the Coriolis parameter. $g$ is the acceleration of gravity, $\eta$ is the bottom displacement, $r$ is the coefficient of bottom friction, and $D$ is the water depth. The Coriolis force may become important for trans-Pacific tsunamis but can be ignored for tsunamis traveling short distances, and the bottom friction can be also ignored for tsunamis traveling a deep sea such as is considered in this study. If the amplitude of a tsunami is small compared to the water depth, the advection terms $u \partial u / \partial x \quad v \partial u / \partial y \quad u \partial v / \partial x \quad v \partial v / \partial y$ can also be neglected so that the equations of motion become linear [Murty, 1977] and can be written as

$$
\frac{\partial u}{\partial t}=-g \frac{\partial H}{\partial x} \quad \frac{\partial}{\partial t}=-g \frac{\partial H}{\partial y}
$$

The phase velocity $c$ of a small-amplitude or linear gravity wave is given by $[$ Lamb , 1932]

$$
c=\sqrt{(g / k) \tanh (k D)}=\sqrt{(g \lambda / 2 \pi) \tanh (2 \pi D / \lambda)}
$$

where $k$ is the wavenumber and $\lambda$ is the wavelength. If $D / \lambda$ is small, the longwave approximation holds, and (3) gives $c=\sqrt{ } g D$. If $\mathrm{D} / \lambda$ is larger than 0.3 , (3) gives $c=\sqrt{ } g \lambda / 2 \pi$, resulting in dispersion. This corresponds to the deepwater or shortwave approximation. Since the amplitudes of the observed tsunamis investigated in this study, $\sim 1 \mathrm{~m}$, are much smaller than the water depth, $\sim 10^{3} \mathrm{~m}$, and the wavelength of the tsunami is much larger than the water depth, the longwave approximation is valid and the associated error is less than several percent.

We introduce $x$ and $y$ components of vertically averaged flow rates, $Q_{x}$ and $Q_{y}$, by integrating the velocity vertically from the bottom to the surface. Then (2) can be written as

$$
\frac{\partial Q_{x}}{\partial}=-g D \frac{\partial H}{\partial x} \quad \frac{\partial Q_{y}}{\partial t}=-g D \frac{\partial H}{\partial y}
$$

and the continuity equation is

$$
\frac{\partial H}{\partial t}=-\frac{\partial Q_{x}}{\partial x}-\frac{\partial Q_{y}}{\partial y}
$$

We used a finite difference method [Aida, 1978] to solve (4) and (5) for the actual bathymetry near the Hawaiian Islands. The area for tsunami computation, $5^{\circ} \times 5^{\circ}$, is shown in Figure la. The grid spacing for the finite difference computation is $1 \mathrm{~min}$. which is $\sim 1.76$ and $1.85 \mathrm{~km}$ in the $x$ and $y$ directions, respectively. We chose the grid spacing to be less than one eighth of the source size to prevent numerical dispersion [Satake, 1987]. The total number of grid points is 90,000 . We chose the time step in the computation to be $2 \mathrm{~s}$ to satisfy the stability condition for finite difference methods [Aida, 1969]. The water depths at the tidegauge stations are $20 \mathrm{~m}$ for Honolulu. $10 \mathrm{~m}$ for Hilo, and $64 \mathrm{~m}$ for Kahului.

The propagation velocity of tsunami is much smaller than that of any kind of seismic waves or rupture velocity of the fault. Kajiura [1970] discussed the energy exchange between the seafloor and the water using a longwave approximation and showed that if the deformation is completed in less than several minutes, it can be treated as an instantaneous change. Thus, if the source-process time of the Kalapana earthquake is less than a few minutes, we can assume that the water surface is uplifted in exactly the same way as the seafloor. We use the instantaneous change of the uplift of the water surface as the initial condition for tsunami computation. If the source duration is much longer than several minutes, only part of the seafloor deformation contributes to tsunami excitation.

\section{Ando's Fault Model}

We first computed tsunamis using the fault model determined by Ando [1979]. Figure 5 shows the vertical component of crustal deformation computed for Ando's fault model to be used as the initial condition. The maximum uplift of the seafloor is $\sim 50 \mathrm{~cm}$, and the maximum subsidence onshore is $\sim 150 \mathrm{~cm}$. We call the area on the seafloor where the vertical displacement is larger than $5 \mathrm{~cm}$ the tsunami source area. The average uplift over the tsunami source area is $\sim 20 \mathrm{~cm}$.

To investigate the contribution of the seafloor deformation to the observed tsunamis, we computed an inverse traveltime diagram using a finite difference method. We put a source at the three tide-gauge stations, Hilo, Honolulu, and Kahului, and propagated tsunamis backward into the ocean. Figure 6 shows the inverse travel time isochrons near the source area at every minute from 20 to 25,45 to 50 , and 40 to $50 \mathrm{~min}$ for Hilo, Honolulu, and Kahului tide-gauge stations, respectively. The isochrons for Hilo, Honolulu, and Kahului intersect at 24, 49, and $48 \mathrm{~min}$, respectively, which are close to the tsunami arrival times at each station. Hereafter, we call these isochrons the onset-time isochrons. The $0 \mathrm{~cm}$ contour line for the vertical crustal deformation caused by the fault model, shown in Figure 5 , is located significantly offshore of the intersection of the onset-time isochrons. Since the beginning of the tsunami is caused by the seafloor deformation near the $0 \mathrm{~cm}$ contour, this result indicates that the first arrivals of the synthetic tsunamis computed for Ando's fault model would be too early compared with the observed arrivals.

Figure 7 compares the synthetic tsunamis computed for Ando's [1979] fault model with the observed tsunamis. As in most tsunami modeling studies, we compare mainly the first cycles. The later part of the records are usually contaminated by waves reflected from the shore near the tide-gauge station. The

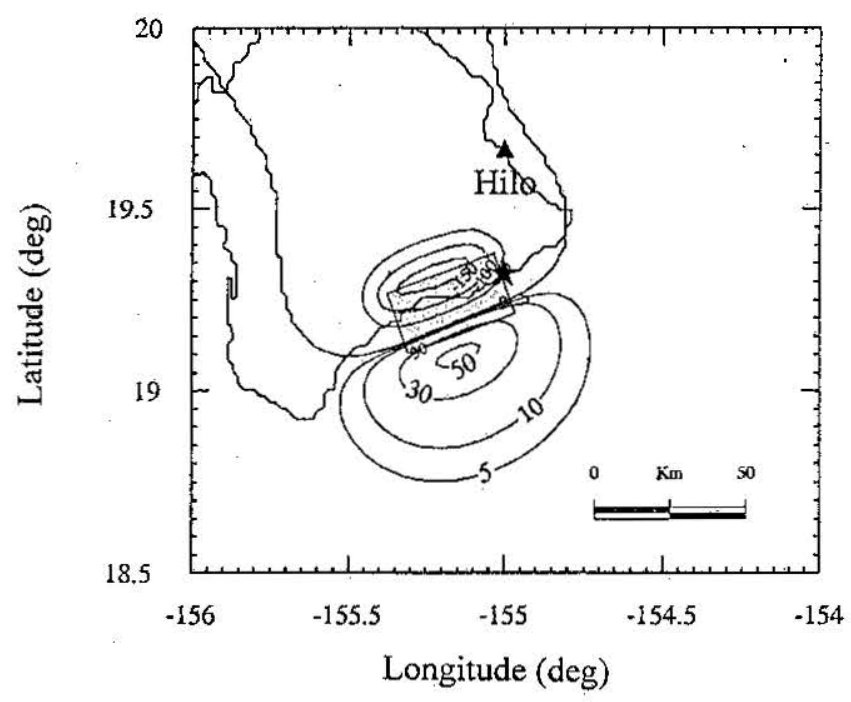

Figure 5. Vertical crustal deformation in centermeters for Ando's fault model. 


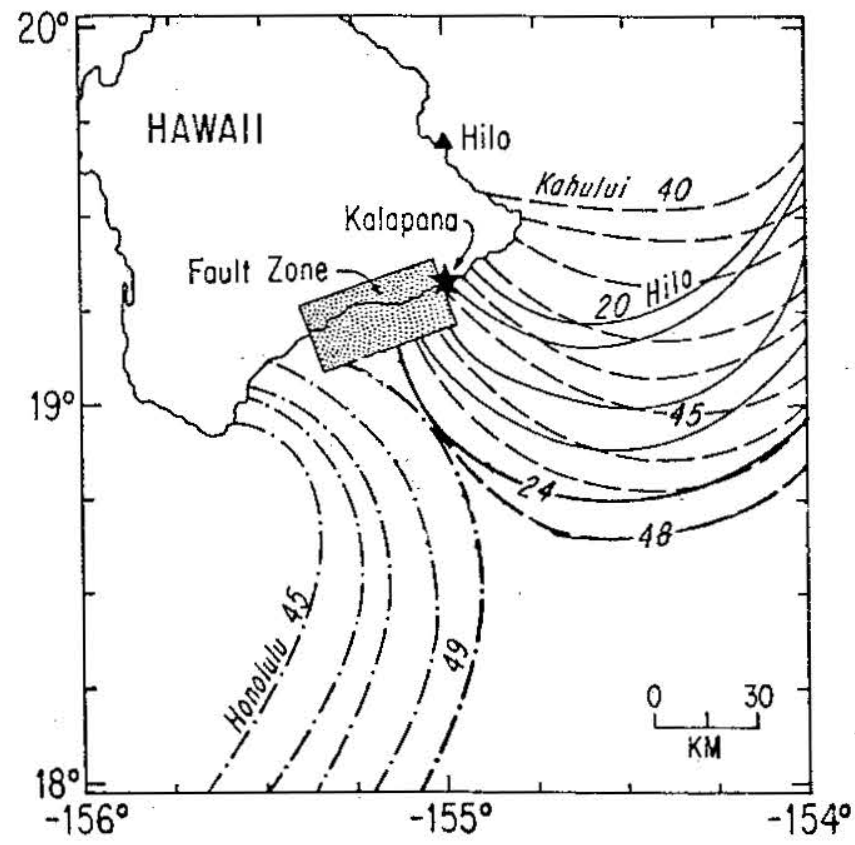

Figure 6. Inverse travel time isochrons. The solid, dash-doted. and dashed curves indicate the tsunami wave fronts at every minute from 20 to 25,45 to 5 , and 40 to $50 \mathrm{~min}$ for Hilo. Honolulu, and Kahului stations, respectively. The bold curves indicate the onset-time isochrons. The asterisk indicates the epicenter of the earthquake. The shaded arca represents the fault plane.

synthetics are too early in arrival time, as we expected, and too small in amplitude compared with the observed. Since the record at Kahului has a large long-period background noise, the beginning is somewhat ambiguous, but the arrival time of the first peak of the synthetic is earlier than that of the observed. The first arrival times of the synthetics are $\sim 10 \mathrm{~min}$ too early, and the peak to peak amplitudes of the synthetics are about one fifth of the observed. Since the average uplift for Ando's model is $\sim 20$ $\mathrm{cm}$, this result suggests that an average of $\sim 1 \mathrm{~m}$ uplift over the tsunami source area would be required to explain the observed amplitudes.

\section{Comparison With Geodetic Data}

Since the observed tsunami could not be simply explained by Ando's fault model, we considered the vertical displacements determined by geodetic surveys onshore [Lipman et al., 1985, Figure 2] to constrain the fault models. We compared the vertical ground deformation on land from various fault models with different dip angles and fault depths to the observed geodetic data. Then we computed tsunamis for those fault models and compared them with the observed.

Figure 8 shows the displacement along the profile $\mathrm{AA}^{\prime}$ passing through Halape as shown in Figure 2. The first trough of the displacement profile to the north is near the summit of Kilauea volcano. 'The steep gradient near $\mathrm{A}^{\prime}$ is located near the Hilina fault system and is probably caused by displacement on it. The segment $\mathrm{A}^{\prime} \mathrm{A}^{\prime \prime}$ in Figure 8 covers the offshore area. From the comparison of the tsunami amplitudes for Ando's fault model with the observed we suggested earlier that an average displacement of $1 \mathrm{~m}$ offshore is required to explain the observed tsunamis. This average is indicated in Figure 8.

The dip angle of the fault model of the 1975 Kalapana earthquake is not very well determined. Ando's [1979] solution is a normal fault dipping $20^{\circ} \mathrm{SE}$, while Furumoto and Kovach's [1979] solution is a thrust fault dipping $4^{\circ} \mathrm{NW}$ (Figure 1c). Given this uncertainty, we computed the vertical crustal deformation profiles along $\mathrm{AA}^{\prime \prime}$ for fault models with dip angles of $20^{\circ} \mathrm{SE}$ (Ando's [1979] model), $10^{\circ} \mathrm{SE}, 0^{\circ} .4^{\circ} \mathrm{NW}$ (Furumoto and Kovach's [1979] model) and $10^{\circ} \mathrm{NW}$. The results are shown in Figure 8. The fault parameters for these models, other than the dip angle, are the same as in Ando's model with a fault slip of $5.5 \mathrm{~m}$. As the dip direction changes from SE to NW, the amount of subsidence onshore decreases, but the amount of uplift offshore increases. The model dipping $20^{\circ} \mathrm{SE}$ yields a maximum subsidence of $\sim 170 \mathrm{~cm}$ and a maximum uplift of only

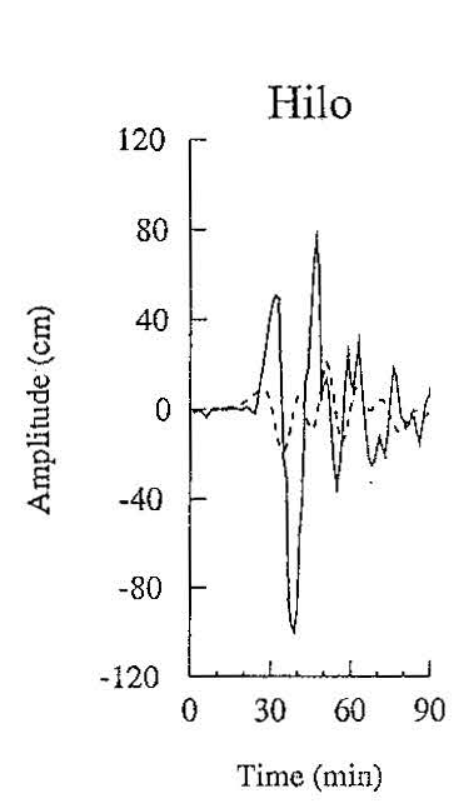

\section{Ando's Model}
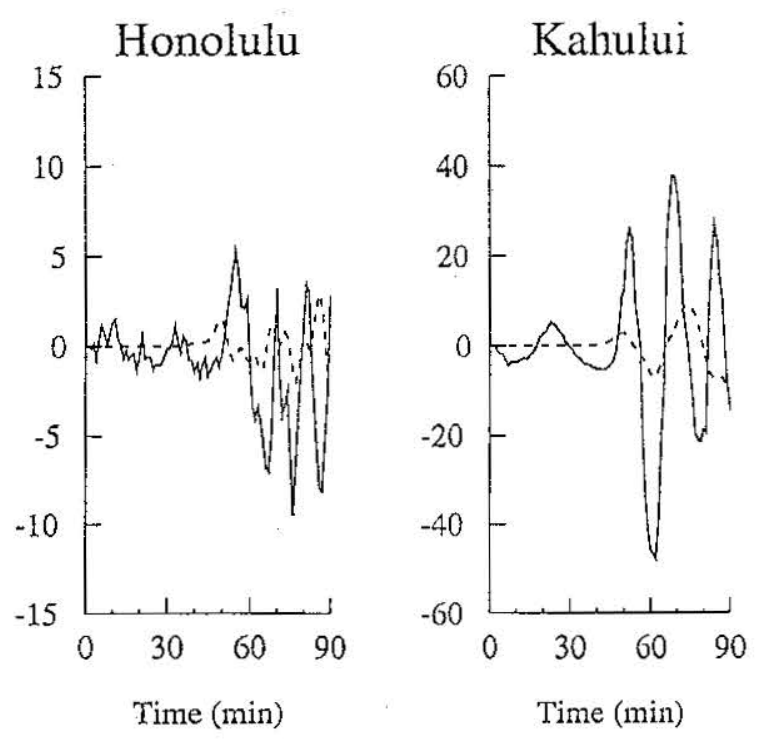

Figure 7. Comparison of the synthetic tsunamis (dashed curve) computed for Ando's fault model with the observed (solid curve). 


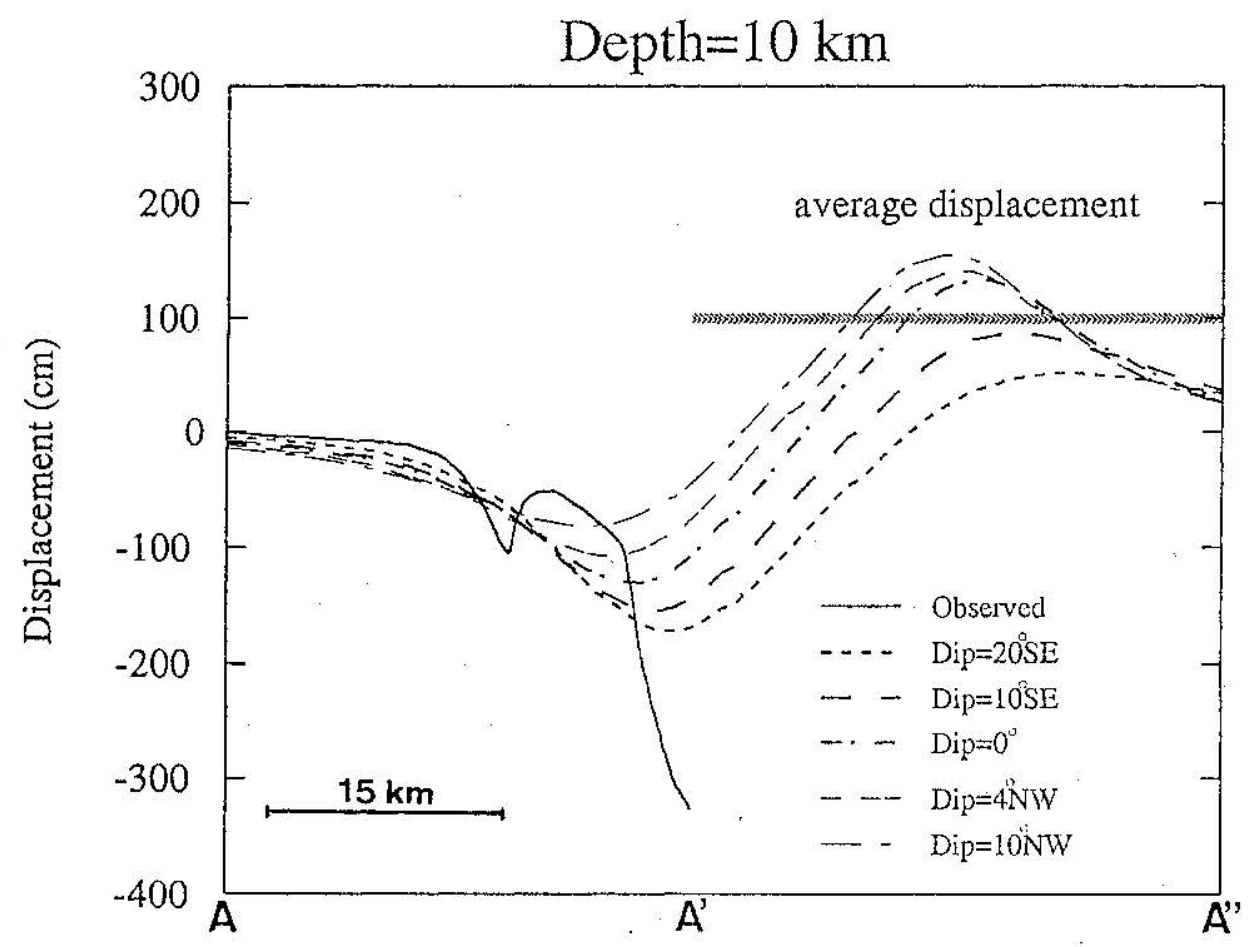

Figure 8. Comparison of the vertical displacements along $\mathrm{AA}^{\prime \prime}$ computed for five fault models with dip directions $20^{\circ} \mathrm{SE}, 10^{\circ} \mathrm{SE}, 0^{\circ}, 4^{\circ} \mathrm{NW}$, and $10^{\circ} \mathrm{NW}$. The upper edge of the fault is at $10 \mathrm{~km}$. The observed leveling data and the average displacement offshore required to explain the observed tsunami are shown by solid and shaded curves, respectively.

$50 \mathrm{~cm}$. In contrast, the model dipping $10^{\circ} \mathrm{NW}$ yields a maximum subsidence of $80 \mathrm{~cm}$ and a maximum uplift of $\sim 150 \mathrm{~cm}$ offshore. Except for the steep gradient inland near Kilauea summit and in the Hilina fault system the trend of the subsidence profiles inland for these fault models is similar to that of the observed. Although the large subsidence near the coast could be modeled by increasing the displacement on the fault, a fault displacement much larger than $5.5 \mathrm{~m}$, which was taken from Ando's model and used in this computation. would be incompatible with the amount of subsidence onshore.

To see the contribution of the vertical deformation offshore of these fault models to tsunamis, we computed synthetic tsunamis for these fault models; the results are shown in Figure 9 in comparison with the observed (the result for Ando's model is shown in Figure 7). As expected, the synthetic tsunamis for the model dipping $10^{\circ} \mathrm{NW}$ yield the largest amplitudes. The amplitude for this fault model is similar to that observed at Honolulu but still too small at the other two stations. We computed the amplitude ratios of the first cycle of the synthetic to the observed for each station and averaged them. The average ratios, shown in Figure 10, are $\sim 0.16,0.28,0.45,0.55$ and 0.66 for the models with dip angles of $20^{\circ} \mathrm{SE}, 10^{\circ} \mathrm{SE}, 0^{\circ}, 4^{\circ} \mathrm{NW}$ and $10^{\circ} \mathrm{NW}$, respectively.

We next examine the effect of the depth of faulting on tsunami excitation. The estimated depth of the fault ranges from 6 to 9 $\mathrm{km}$. We computed the vertical crustal deformation for fault models with the upper edge at depths of $\mathrm{d}=3,5,7$, and $10 \mathrm{~km}$ and dip angles of $10^{\circ} \mathrm{SE}, 0^{\circ}$, and $10^{\circ} \mathrm{NW}$. Figures $11 \mathrm{a}, 11 \mathrm{~b}$, and $1 \mathrm{lc}$ show the vertical crustal deformation profiles along $\mathrm{AA}^{\prime \prime}$ for these models. The fault models with shallower depths yield more localized patterns of subsidence and uplift regardless of the dip angle. Figures $12 \mathrm{a}, 12 \mathrm{~b}$ and $12 \mathrm{c}$ show the synthetic tsunamis for the models with $\mathrm{d}=3 \mathrm{~km}$ and dip directions of $10^{\circ} \mathrm{SE}, 0^{\circ}$, and $10^{\circ} \mathrm{NW}$, respectively. The synthetics for $\mathrm{d}=3$ $\mathrm{km}$ are similar to those for the corresponding model with $\mathrm{d}=10$ $\mathrm{km}$ (Figure 9). The amplitude ratios for $\mathrm{d}=3 \mathrm{~km}$ are slightly smaller than those for $d=10 \mathrm{~km}$ (Figure 10 ), but the shallow models yield later arrivals of the tsunamis because the area of the uplift offshore for shallow models occurs farther from the tidegauge stations than that for deep models. Since the strike of the fault does nol affect the pattern of the vertical crustal deformation, we did not test the fault models with different strikes.

Previous studies show that the largest dip angle of the fault model for the 1975 Kalapana earthquake dipping NW is $4^{\circ} \mathrm{NW}$ [Furumoto and Kovach, 1979], and the shallowest fault depth is 6 $\mathrm{km}$ [Wyss and Kovach, 1988]. The distribution of earthquakes beneath the south flank recently determined by Denlinger and Okubo [1995] clearly delineates an almost horizontal plane at a depth of 7-10 km [Denlinger and Okubo, 1995, Figure 5]. A very precise determination by Got et al. [1994] suggests a dip angle of $6^{\circ} \pm 4^{\circ} \mathrm{NW}$, but it represents a local area near the upper south flank, and the average dip in the south flank is considerably smaller than this. Considering the surface topography of the south flank of Kilauea, the depth and the dip angle of the slip plane defined by seismicity is deeper than $6 \mathrm{~km}$ and smaller than a few degrees (NW). Figure 10 shows that the amplitude ratio is still $\sim 0.5$ even for a model with a dip of $4^{\circ} \mathrm{NW}$, and the arrivals of the synthetics are still too early (Figure 12) even for a very shallow fault model $(\mathrm{d}=3 \mathrm{~km})$. Thus we conclude that an earthquake fault model with a width of $20 \mathrm{~km}$ alone might not be able to explain the observed tsunamis.

We also note that the steep gradient of subsidence near the coast on the profile $\mathrm{AA}^{\prime}$ (Figure 8) cannot be explained by earthquake fault models. Since this subsidence can be important 

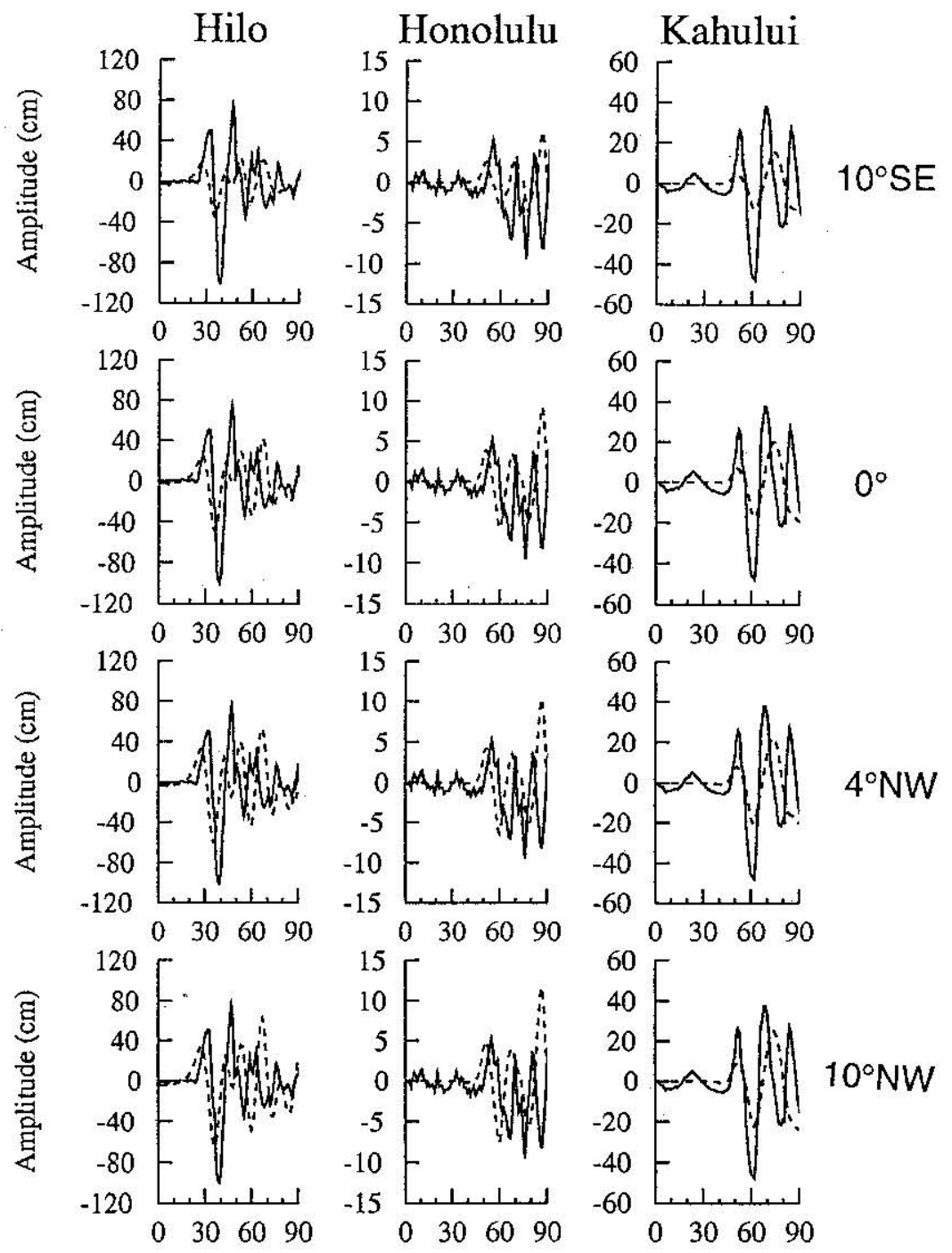

Time (min)

Time (min)

Time (min)

Figure 9. Comparison of the synthetic tsunamis (dashed curves) for fault models with dip angles of $10^{\circ} \mathrm{SE}, 0^{\circ}$. $4^{\circ} \mathrm{NW}$, and $10^{\circ} \mathrm{NW}$ with the observed tsunamis (solid curves). The upper edge of the fault is at $10 \mathrm{~km}$.

for understanding the origin of the observed tsunamis, we next consider the displacement on the Hilina fault system.

The steep gradient of subsidence near the coast is probably due to the slip on the Hilina fault system. The Hilina fault system is characterized by south facing normal fault scarps as high as 500 $m$. Surface breaks occurred during the 1975 Kalapana earthquake extending $-25 \mathrm{~km}$ along the trend of the Hilina fault system, and the individual faults produced a vertical displacement of as much as $1.5 \mathrm{~m}$ [Lipman et al., 1985].

The trace of the Hilina fault system is well defined, $\sim 40 \mathrm{~km}$ long and $5 \mathrm{~km}$ wide, with a strike of about $\mathrm{N} 60^{\circ} \quad \mathrm{E}$ and a dip of $\sim 60^{\circ}-80^{\circ} \mathrm{SE}$ [Lipman et al., 1985]. Aithough the depth extent of faulting associated with the 1975 Kalapana earthquake is not known, this geometry would yield the steep gradient seen in the observed vertical displacement near the coast. For example, if we add a Hilina fault model with a displacement of $3.7 \mathrm{~m}$ (strike $=\mathrm{N} 60^{\circ} \mathrm{E}$ and dip $=70^{\circ} \mathrm{SE}$ ), a fault area of $40 \mathrm{~km}$ (length) $x 5 \mathrm{~km}$ (down dip width), and an upper edge of the fault at $3.5 \mathrm{~km}$

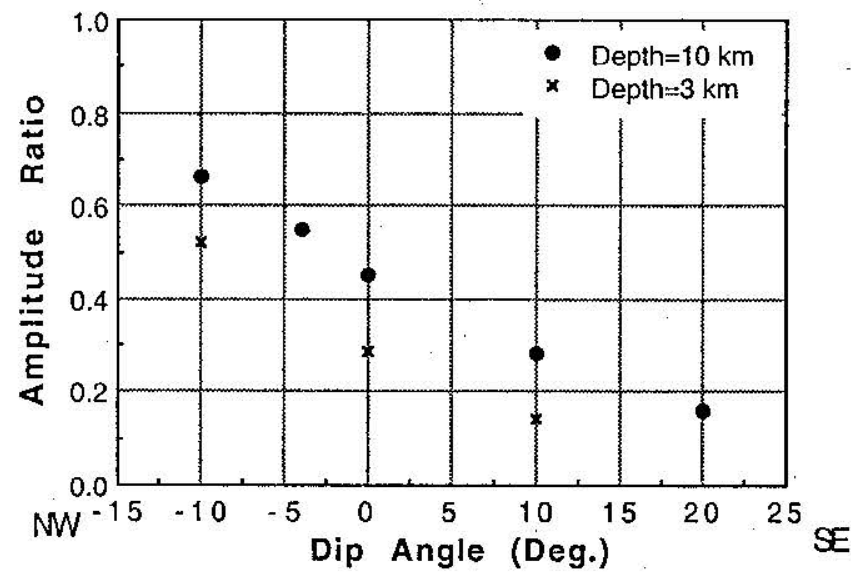

Figure 10. The average amplitude ratio of the first cycle of the synthetic to the observed for fault models with the upper edge of the fault at $10 \mathrm{~km}$ (solid circle) and $3 \mathrm{~km}$ (cross). 


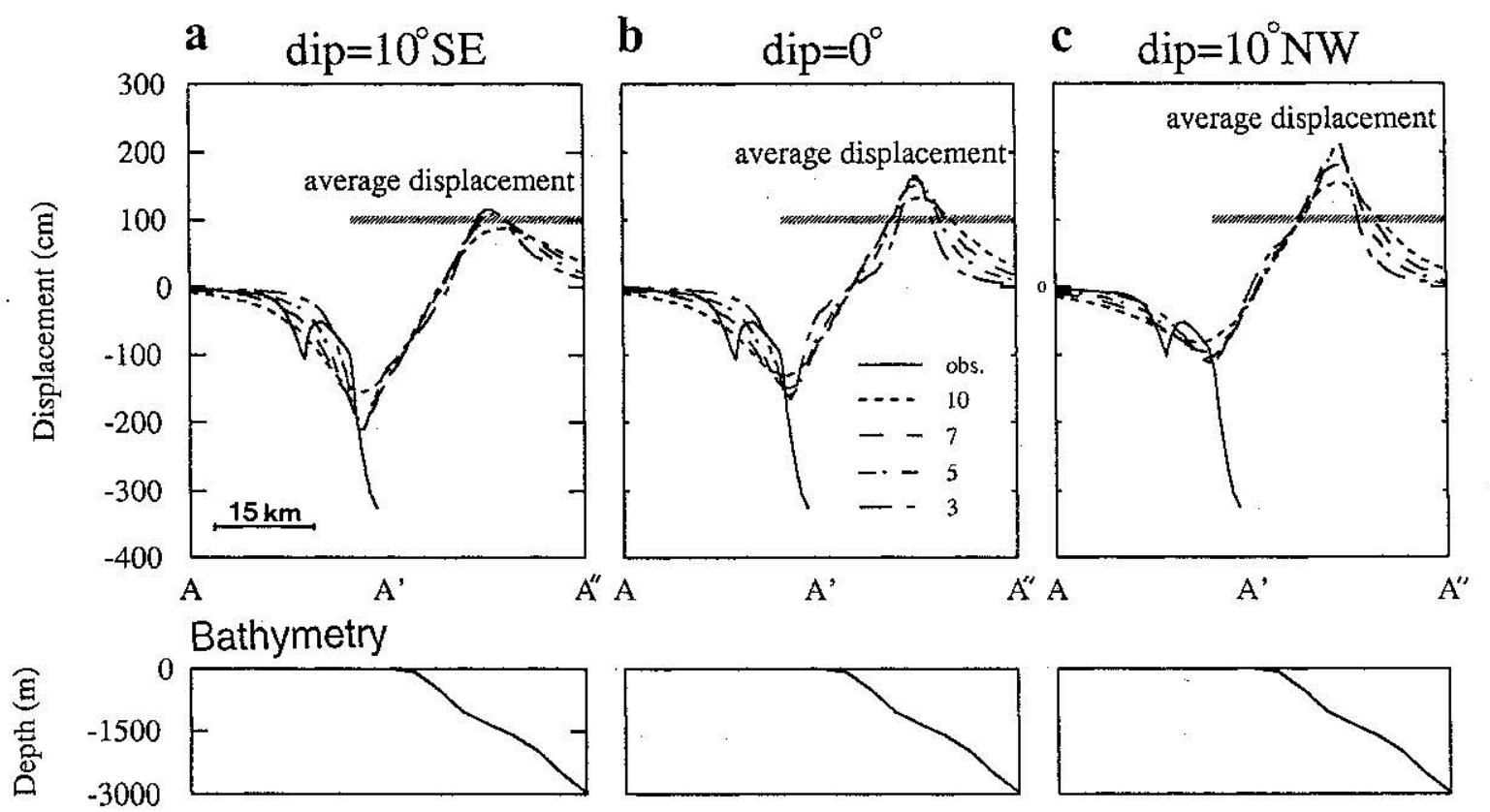

Figure 11. Comparison of the vertical crustal deformation for fault models with the upper edge of the fault at depths of $10,7,5$, and $3 \mathrm{~km}$ with the observed deformation (solid curve) inland and the required average uplift (shaded line) offshore. Comparisons for fault models with dip angles of (a) $10^{\circ} \mathrm{SE}$, (b) $0^{\circ}$, and (c) $10^{\circ} \mathrm{NW}$ are shown. The bottom boxes indicate the bathymetry along the profile AA".

to the main fault model dipping $10^{\circ} \mathrm{SE}$ at depth of $3 \mathrm{~km}$, we can explain the overall pattern of the profile $\mathrm{AA}^{\prime}$ as shown in Figure 13. This solution is nonunique since other models could be obtained by adjusting the amount of slip and the depth of the upper edge of the fault. However, the synthetic tsunami from the Hilina fault system model contributes insignificantly to the overall tsunami excitation, as shown in Figure 14.

\section{Slump Model}

From the results of various studies mentioned above it seems reasonable to assume an essentially horizontal slip plane at a depth of $\sim 10 \mathrm{~km}$. From the magnitude of the geodetic deformation the average slip on this plane is estimated to be $\sim 5 \mathrm{~m}$. As shown in Figures 9 and 10, this model explains only about half the observed tsunami amplitudes. This discrepancy was already noted by Ando [1979]. One might conclude that considering all the uncertainties in the tide-gauge data and the limitations in tsunami waveform computations (e.g., reflections from the coast are ignored.), this discrepancy is not significant. However, although it is difficult to assess the real uncertainties in tsunami modeling, considering the many successful modeling studies of the first-motion waveforms of tide gauge data [Imamura et al., 1993, 1995; Johnson et al., 1996; Johnson and Satake, 1997], we feel that it is worthwhile to try to explain this discrepancy by modifying the conventional dislocation models. To remove the discrepancy between the observed and computed tsunami shown in Figure 9, some additional uplift of the seafloor is required. Although we cannot determine this source uniquely, we first invoke a slump feature on the seafloor.

Lipman et al. [1985] showed that the onshore extensionat ground deformation related to the 1975 earthquake and associated normal faults were as much as $3.5 \mathrm{~m}$. vertically and $8 \mathrm{~m}$ horizontally. The maximum horizontal displacement occurred in the same area of south flank as the maximum subsidence
(Figures 2 and 3 ). Combining these observations with the asymmetry of the deformation (the gradient of subsidence along the south flank of Kilauea decreases more rapidly west of Halape than east), they suggested that the initial earthquake triggered a sequence of deformation that migrated westward along the Hilina fault system. The ratio of horizontal to vertical displacement associated with the 1975 Kalapana earthquake suggests a gravitational slump. Lipman et al. [1985] also observed new ground breakages in the Hilina fault system, as much as $1 \mathrm{~m}$ along the southwestern part but minimal along the eastern part of the Hilina fault system; none was found near the epicenter. Widening of many cracks occurred within the Hilina fault system, which indicated significant horizontal extension. The patterns of ground breakage along the Hilina fault system and the leveling contours showing the maximum gradients of subsidence in the same area also offer convincing evidence that much of the earthquake-related deformation involved seaward gravitationa! slumping or block sliding.

As mentioned earlier, the beginnings of the upward motion are at $\sim 23,48$, and $49 \mathrm{~min}$ after the origin time at Hilo. Honolulu, and Kahului, respectively. Hence, if slumping occurred at the same time (within a minute or so) as the earthquake, the slump source must be located near the point where the corresponding isochrons (Figure 6) come close to each other. Considering the large subsidence along the Halape coast (Figure 2), we constructed a propagating slump model with subsidence in the coastal area as shown in Figure 15a. We divided the large source area shown in Figure 15a into 12 blocks, each block having an area of 9x9 min. We assume a $1 \mathrm{~m}$ coseismic subsidence in the three blocks along the coast and a $1 \mathrm{~m}$ uplift in the remaining 9 blocks $\left(\sim 2500 \mathrm{~km}^{2}\right)$ with delays shown in Figures. The amount of subsidence was determined from the average subsidence along the coast. We estimated the time delays for each block of the propagating uplift from the isochrons shown in Figure 6. Figure 16a shows the synthetic tsunamis 


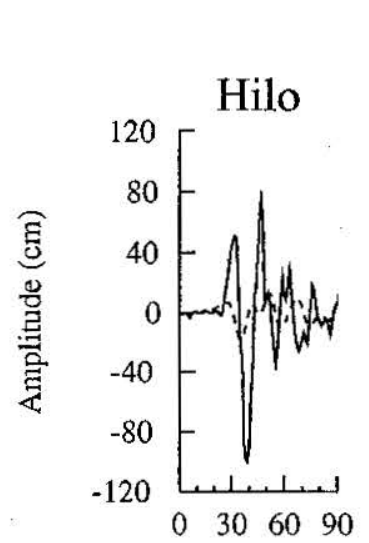

\section{Depth=3 km}
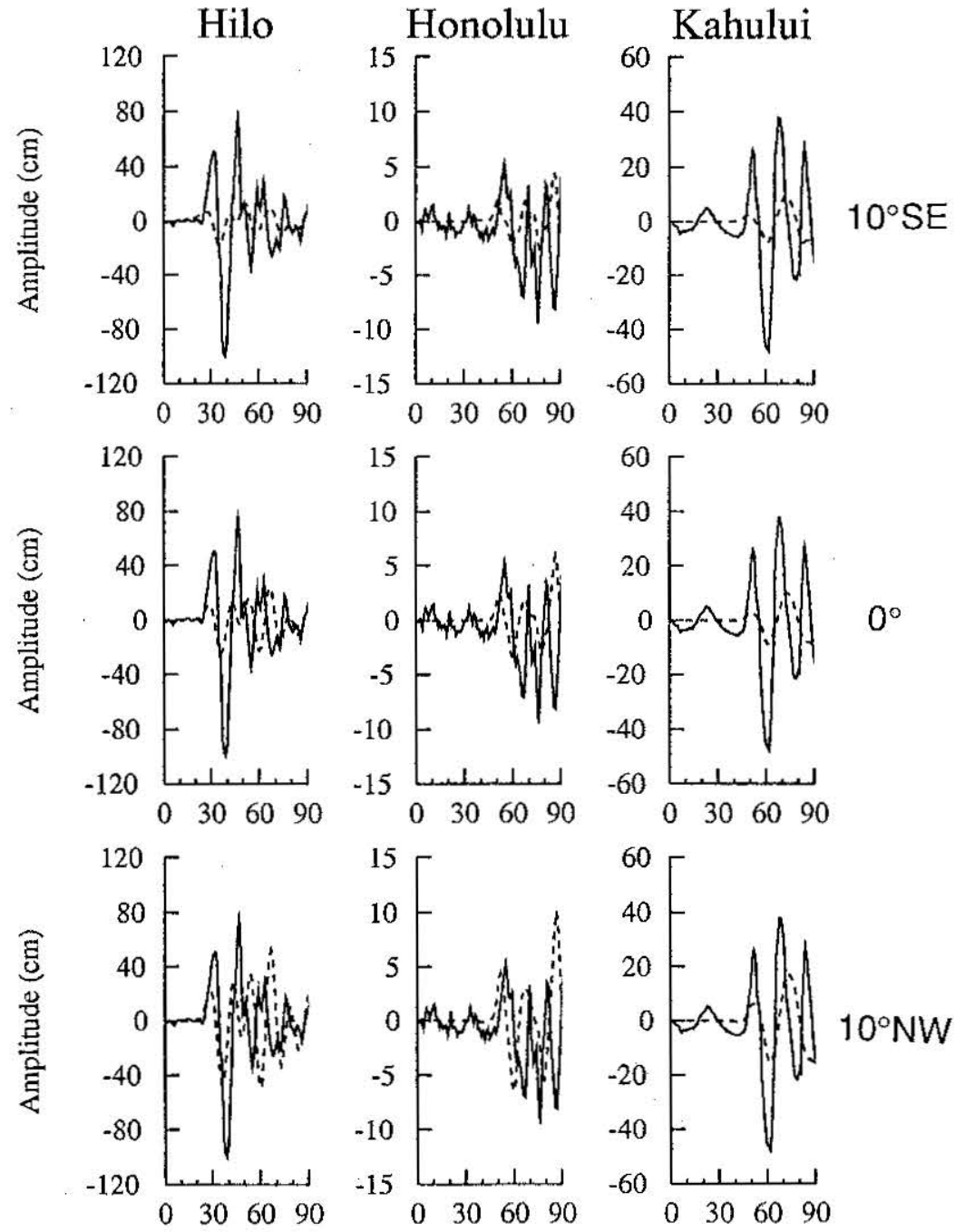

Time (min)

Time (min)

Time (min)

Figure 12. Comparison of the synthetic tsunamis (dashed curve) computed for fault models with dip angles of $10^{\circ} \mathrm{SE}, 0^{\circ}$, and $10^{\circ} \mathrm{NW}$ and the upper edge of the fault at a depth of $3 \mathrm{~km}$ with the observed tsunamis (solid curve).

computed for the slump model. As shown in Figure 16b, the model, which consists of faulting on a horizontal plane at a depth of $10 \mathrm{~km}$, a Hilina fault model, and a slumping, explains the arrival times of the distinct upward motions, amplitudes, and periods of the observed tsunamis satisfactorily. From the uplifted area of the slump source we estimate the volume of displaced water to be $\sim 2.5 \mathrm{~km}^{3}$. Although the model is not unique, the pattern of subsidence and propagating uplift shown in Figure $15 \mathrm{a}$ is a reasonable model for a rotational slumping, as shown in Figure 17.

The volume of the displaced water, $2.5 \mathrm{~km}^{3}$, we obtained is comparable to the estimates of Hatori [1976] and Lipman et al. [1985]. Chadwick et al. [1993] used the multibeam sonar and improved satellite navigation systems to obtain the detailed bathymetric map for the submarine flanks of the active volcanoes of Hawaii. The area obtained in our study, $2500 \mathrm{~km}^{2}$, is close to the size of offshore bench, $2800 \mathrm{~km}^{2}$, in their modern bathymetric data [Denlinger and Okubo, 1995].

\section{Wide Fault Model}

The fault models used above all have a width of $20 \mathrm{~km}$, which is chosen to be compatible with the extent of the aftershock area. However, if we extend the fault plane seaward toward the toe of the south flank slope, well beyond the aftershock area, we can produce larger uplift, which can contribute to tsunami excitation. We investigate this model in the following.

We consider a wide fault model with a width of $40 \mathrm{~km}$ with a dip angle of $\sim 10^{\circ} \mathrm{NW}$ and $5.5 \mathrm{~m}$ slip on the fault shown in Figure 18. This model is suggested by R.S.Crosson (personal communication, 1994). The fault plane is placed on the boundary between the oceanic crust and the layer consisting of the volcanic material. Although the dip angle of this boundary is $\sim 5^{\circ} \mathrm{NW}$. we used a fault model with a dip angle of $10^{\circ} \mathrm{NW}$ for modeling purposes because the topographic slope of $5^{\circ} \mathrm{SE}$ would contribute to additional uplift. As shown in Figure 15b, the vertical displacement field for the wide fault model produces an 


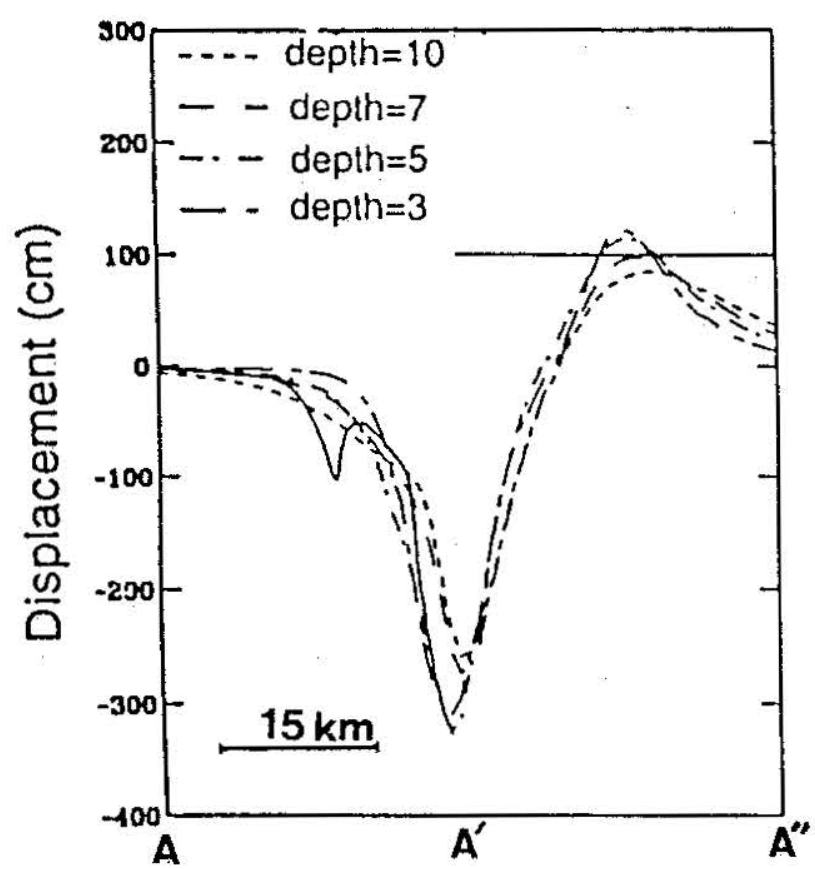

Figure 13. Comparison of the vertical deformation for a composite fault model with the observed. The composite model consists of a fault with a dip angle of $10^{\circ} \mathrm{SE}$ and a depth of $3 \mathrm{~km}$ and the Hilina fault.

average uplift of $\sim 80 \mathrm{~cm}$ over an area of $-2400 \mathrm{~km}^{2}$, which is similar to that for the slump model shown in Figure 15a. Figure 19 shows the synthetic tsunamis computed for the wide fault model with $5.5 \mathrm{~m}$ slip on the fault. The arrival times of the synthetic tsunamis are different from those of the observed tsunamis by $2-5 \mathrm{~min}$, and the average amplitude is $\sim 71 \%$ of the observed. Considering all the uncertainties in the tide-gauge data and the limitations in tsunami waveform computations, the discrepancy between the synthetics and observed is not significant. Minor modifications of the wide fault model would improve the fit. Thus, if we extend the fault plane nearly $25 \mathrm{~km}$ offshore, well beyond the aftershock area, we can explain the observed tsunami without invoking a slumping offshore. In other words, the wide fault model and the slump model are kinematically similar as far as tsunami generation is concerned. Here we prefer the slump model because it is more compatible with the absence of the aftershocks offshore and the deformation pattern in the coastal area described by Lipman et al. [1985].

\section{Comparison With Single Force Model}

We now compare the slump model with the single force model of Eissler and Kanamori [1987]. However, since the singleforce model was obtained from seismic radiation, it cannot be directly compared with the present result. We make only a qualitative comparison in the following.

The single force is a kinematic representation of southeastward slumping of a large block on the south flank of Kilauea. The northern half of this block is onshore and the southern half is oftshore [Eissler and Kanamori. 1987, Figure 12]. Seaward sliding of the offshore part of this wedge-like structure would uplift the seafloor over a large area. The pattern of uplift is consistent with that determined from tsunami data. Since the magnitude of the single force depends on the total mass of the sliding block while tsunami excitation depends only on the area and the amount of uplift, no direct comparison can be made between the magnitude of the single force and tsunami excitation.

The overall magnitude of the slump can be given by the product $M D$ using a centroid single force (CSF) model [Kawakatsu, 1989], where $M$ and $D$ are the total mass of the slump and sliding distance. If we assume a time function of the force to be a simple sinusoid with half-period $\tau$.

\section{Hilina Fault Model}
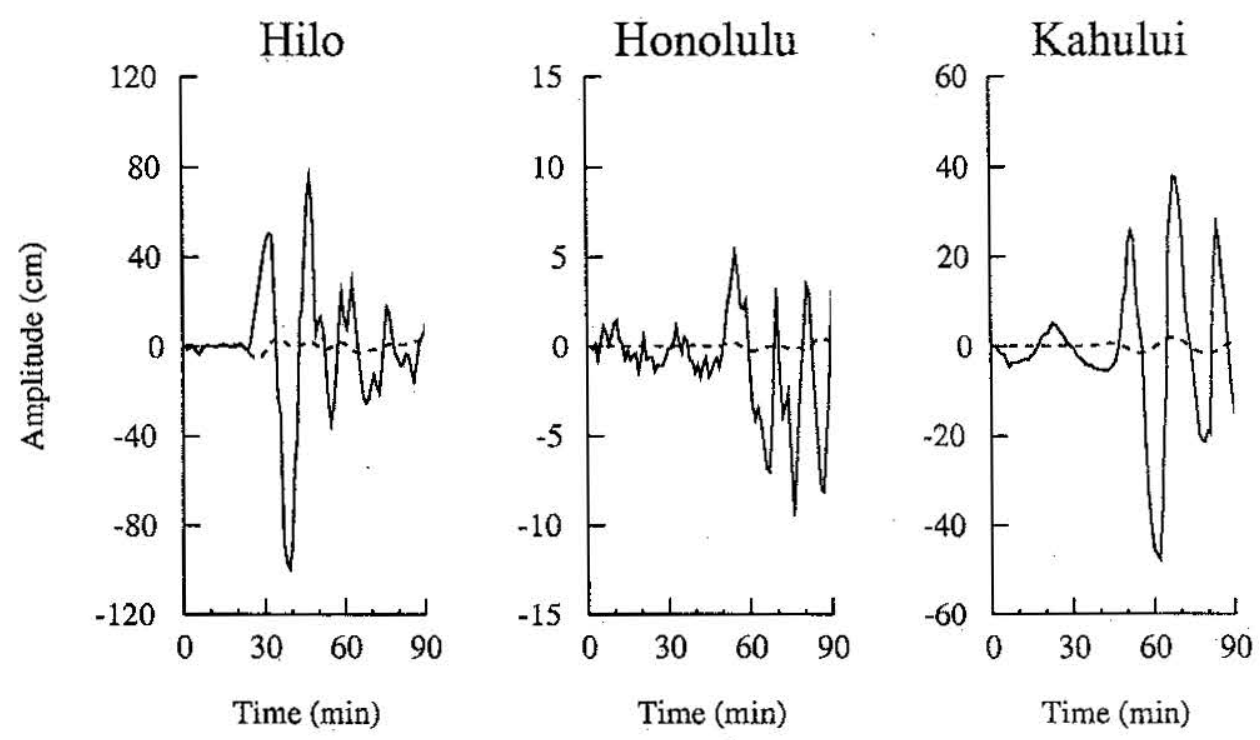

Figure 14. Comparison of the synthetic tsunamis (dashed curve) for a Hilina fault model with the observed tsunamis (solid curve). 

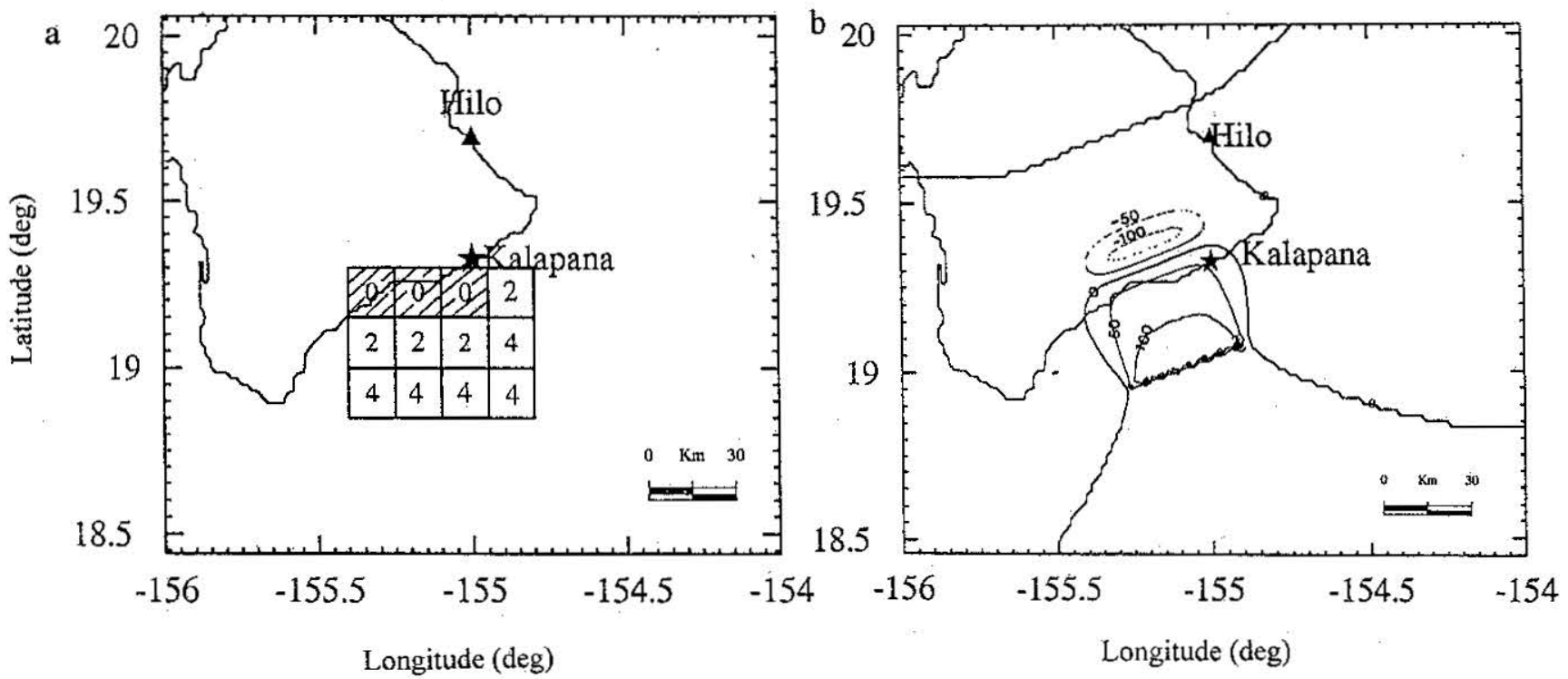

Figure 15. (a) Propagating slump model. Hatched boxes indicate subsidence; and open boxes indicate uplift. A $1 \mathrm{~m}$ coseismic subsidence and a $1 \mathrm{~m}$ uplift are assigned in the subsidence and uplift boxes, respectively. The uplifted area is $-2500 \mathrm{~km}^{2}$. The numbers in the boxes indicate the delay limes in minutes. (b) The vertical displacement field computed for the wide fault model with a dip angle of $10^{\circ} \mathrm{NW}$ and a width of $40 \mathrm{~km}$. The contour interval is $50 \mathrm{~cm}$. Solid and dashed curves indicate uplift and subsidence of the deformation, respectively.
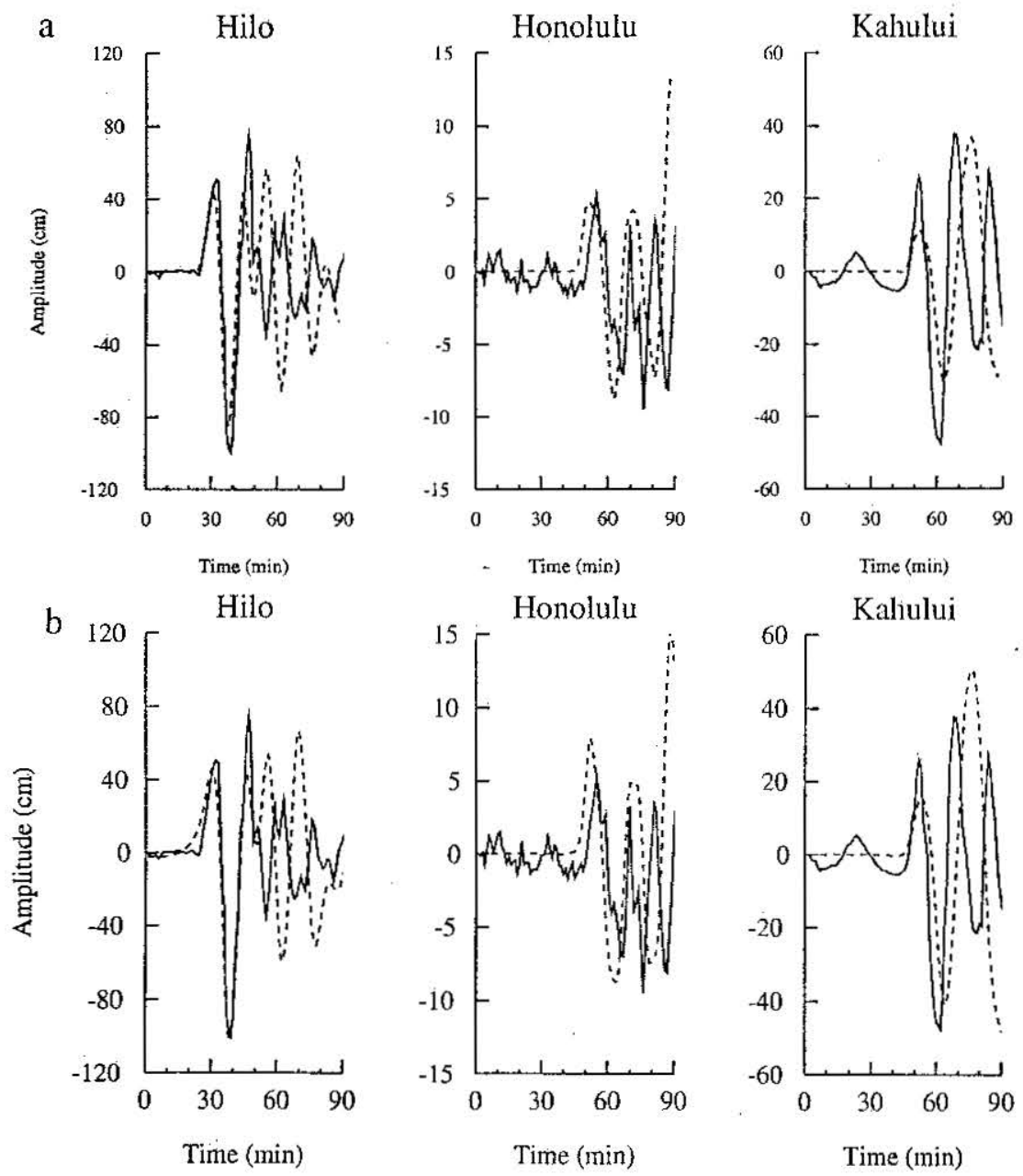

Figure 16. (a) Comparison of the synthetic tsunamis (dashed curve) computed for the slump model with the observed tsunamis (solid curve). (b) Comparison of the synthetic tsunamis (dashed curve) computed for a combination of horizontal fault model at a depth of $10 \mathrm{~km}$, a Hilina fault model, and the propagating slump model (Figure 15) with the observed tsunamis (solid curve). 


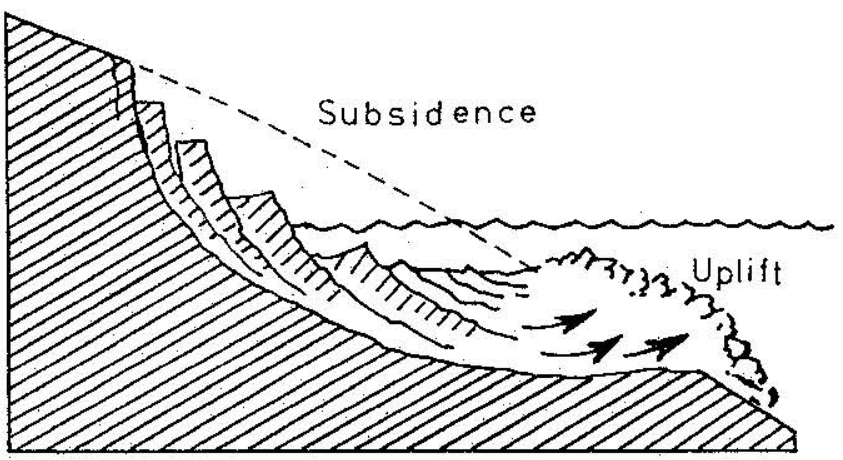

Figure 17. Schematic showing a rotational slumping that causes subsidence and uplift.

$$
\begin{array}{cr}
f_{0} s(t)=f_{0} \sin \left(\frac{\pi t}{\tau}\right) & 0 \leq \mathrm{t} \leq 2 \tau \\
0 & \mathrm{t}>2 \tau
\end{array}
$$

where $f_{0}$ is the peak force, the magnitude of the sluinp can be written as

$$
\begin{aligned}
M D & =p V D \\
& =f_{t} \int_{0}^{2 t}\left[\int_{0}^{t} s\left(\tau^{\prime \prime}\right) d \tau^{\prime \prime}\right] d t \\
& =f_{0} \int_{0}^{2 \tau}\left[\int_{0}^{t} \sin \left(\frac{\pi \tau^{\prime \prime}}{\tau}\right) d \tau^{\prime \prime}\right] d t \\
& =\frac{2 f_{0} \tau^{2}}{\pi}
\end{aligned}
$$

where $\rho$ and $V$ are the density and total volume of the slump and $\tau "$ is the dummy parameter. Eissler and Kanamori [1987] estimated $f_{0}$ to be $\sim 1 \times 10^{15} \mathrm{~N}$ from long-period surface waves. Then they estimated $D$ to be $80-2600 \mathrm{~m}$ for ranges of $M$ and $\tau$ from $10^{15}$ to $10^{16} \mathrm{~kg}$ and 50 to $90 \mathrm{~s}$, respectively. Kawakatsu [1989] applied an inversion method, and using more data than
Eissler and Kanamori [1987], estimated $D$ to be $37-370 \mathrm{~m}$. Since the observed subaerial horizontal displacement increased from $1 \mathrm{~m}$ near the summit of Kilauea to $8 \mathrm{~m}$ at the coast (Figure 3 ), the above value of $D$ suggests that the displacement continued to increase offshore as the slide block deteriorated into a massive sediment slump. The amount of vertical displacement caused by this horizontal displacement depends on the details of the slide geometry. If the slide is a simple wedge with a triangilar shape with a slope $\alpha$, the vertical displacement $H$ is given by Dtan $\alpha$. Eissler and Kanamori's [1987] gravity slide model suggests $\alpha=$ $5^{\circ}$. This slope, however, results in $H=3$ to $227 \mathrm{~m}$, which is too large compared with the uplift estinzated from tsunami data. If the average slope of the offshore slump decreases, $H$ can be reduced accordingly. Although large uncertainties are involved in the determination of $f_{0}$ and $\tau$ and the total volume and geometry of the slide mass are not known well, the above comparison appears to indicate that the magnitude of the single force is 100 large to be consistent with the observed tsunami. Kawakatsu [1989] concluded that neither a double-couple nor single force model can explain the data satisfactorily and suggested a combination of them. If part of the seismic radiation is due to faulting, then the magnitude of the single-force can be reduced and the resulting uplift can be made consistent with that estimated from tsunami data. This is consistent with the argument of Wyss and Kovach [1988] in which the 1975 Kalapana earthquake is viewed as a faulting onshore with secondary normal faulting and slumping in the coastal and offshore areas.

\section{Conclusion}

The synthetic tsunamis computed for Ando's [1979] dislocation model are too early in arrival times and too small in amplitudes. We considered the effects of the Hilina fault system, in addition to the main fault, but the contribution of the Hilina fault system to tsunami excitation is insignificant. We tested a model that consists of faulting on a horizontal plane at a depth of $10 \mathrm{~km}$, a Hilina fauit model, and a simple siump (gravity faulting) model. We found that a propagating slump model with $1 \mathrm{~m}$

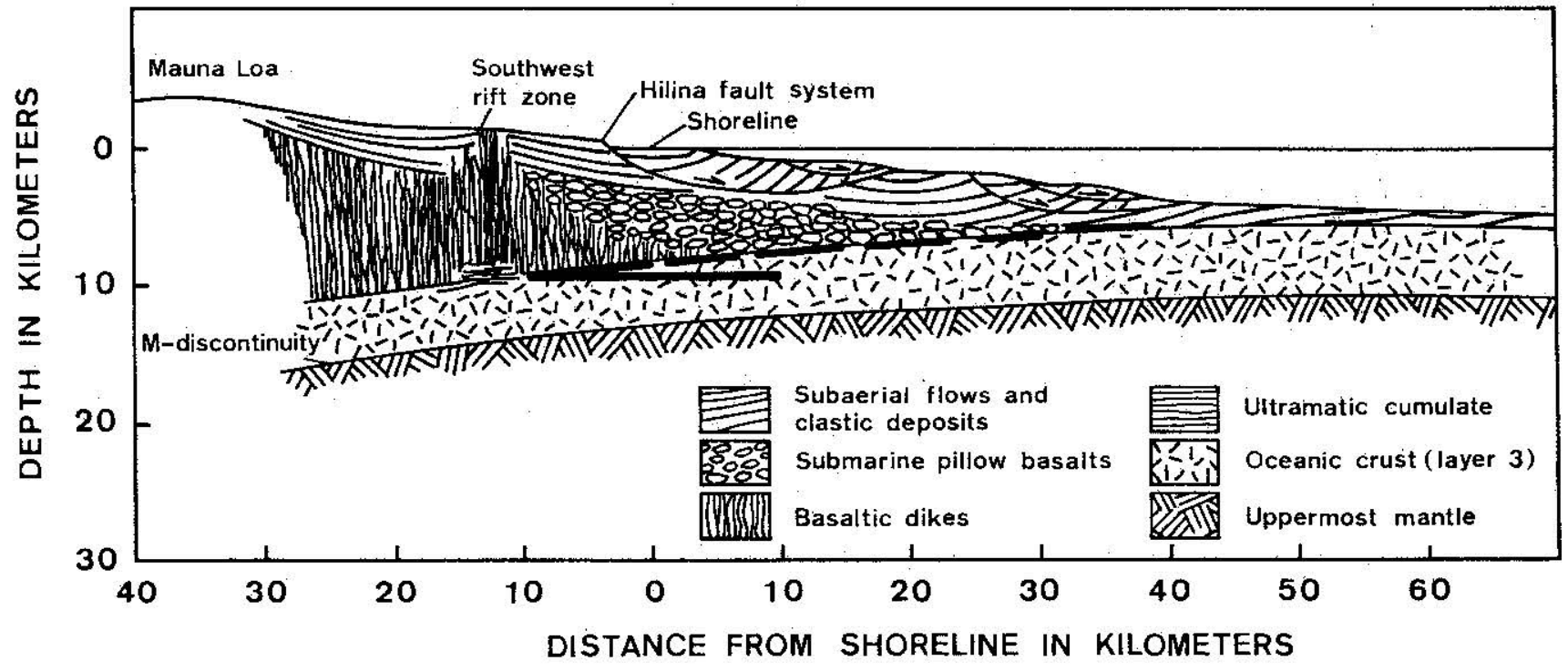

Figure 18. The focation and geometry of the wide fault model (bold dashed line) shown on the cross section given by Hill and Zucca [1987]. The extent of the standard fault models (width $=20 \mathrm{~km}$ ) used in this study is shown by the bold lines. 

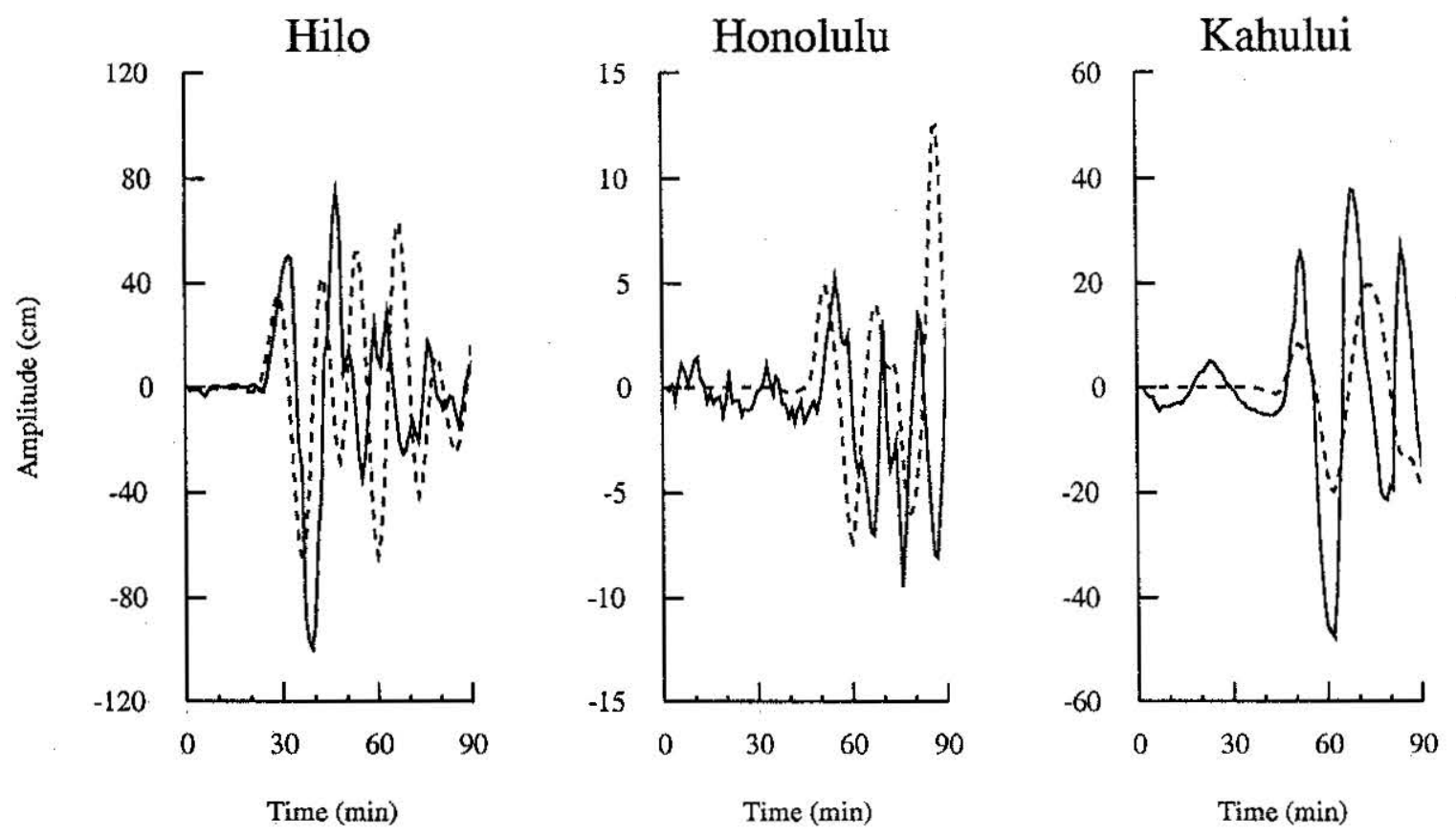

Figure 19. Comparison of the synthetic tsunamis (dashed curve) computed for the wide fault model with the observed tsunamis (solid curve).

subsidence along the coast and $1 \mathrm{~m}$ uplift offshore can explain the arrival times and amplitudes of the tsunamis very well. An alternative model is a wider fault model that dips $10^{\circ} \mathrm{NW}$, with its fault plane extending $25 \mathrm{~km}$ offshore well beyond the aftershock area of the Kalapana earthquake. These two models produce a similar uplift pattern offshore and are kinematically indistinguishable as far as tsunami excitation is concerned. The total volume of displaced water is estimated to be $-2.5 \mathrm{~km}^{3}$. The slumping area used in the calculation is close to the size of $2800 \mathrm{~km}^{2}$ offshore bench in the bathymetry [Chadwick et al., 1993].

From the comparison of tsunami excitation and the singleforce model suggested earlier from seismological data we conclude that a combination of a faulting and a large-scale slumping on the south flank of Kilauea volcano is the most appropriate model for the 1975 Kalapana earthquake. The faulting and slumping are indicative of slope instability of the south flank of Kilauea in response to magmatic or gravitational forces prevailing in the south flank. This model is similar to that envisaged by Wyss and Kovach [1988].

Acknowledgments. We thank the reviewers $R$. Denlinger and $R$. Crosson for critical reading of the manuscript. valuable comments, and suggestions that helped us to improve the manuscript. This work was supported by the National Science Foundation grants EAR-9303804 and EAR-9316528 and National Science Council, Taiwan, contract NSC830202-M-008-050T. Contribution 8487 of the Division of Geological and Planetary Sciences, California Institute of Technology, Pasadena. California.

\section{References}

Aida, I., Numerical experiments for the tsunami propagation: The 1964 Niigata tsunami and the 1968 Tokachi-Oki tsunami. Bull. Earthquake Res. Inst. Univ Tokyo, 47, 673-700, 1969.

Aida, I., Reliability of a tsunami source model derived from fault parameters, J. Phys. Earth, 26, 57-73, 1978.

Ando, M., The Hawaii earthquake of November 29, 1975: Low dip angle faulting due to forceful injection of magma, J. Geophys. Res., 84 , 7616-7626. 1979.

Bryan, C. J.. and C. E. Johnson. Block tectonics of the island of Hawaii from a focal mechanism analysis of basal slip, Bull. Seismol. Soc. Am. 81, 491-507, 1991.

Cox. D. C.. Source of the tsunami associated with the Kalapana (Hawaii) earthquake of November 1975, Rep. 80-8. 46 pp., Hawaii Inst. of Geophys. Univ of Hawaii, Honolulu, 1980.

Chadwick, W. W. J. R. Smith, J. G. Moore, D. A. Clague. M. O. Garcia, and C. G. Fox, Bathymetry of south flank of Kilauea volcano, Hawaii, U. S. Geol. Survey Invest. Map, MF-2231, 1993.

Crosson, R. S., and E. T. Endo, Focal mechanisms and locations of carthquakes in the vicinity of the 1975 Kalapana earthquake aftershock zone 1970-1979: Implications for the tectonics of the south flank of Kilauea volcano. Hawaii. Tectonics, I, 495-542, 1982.

Denlinger, R. P., and P. Okubo, Structure of the mobile south flank of Kilauea volcanoes, Hawaii. J. Geophys. Res., 100, 24,499-24,507, 1995.

Dvorak. J. J. An earthquake cycle along the south flank of Kilauea volcano, Hawaii, J. Geophys. Res., 99, 9533-9541, 1994.

Dvorak, J. J.. A. T. Okamura, T. T. English. R. Y. Koyanagi, J. S. Nakata. M. K. Sako, W. T. Tanigawa, and K. M. Yamashita, Mechanical response of the south tlank of Kilauea volcano. Hawaii, to intrusive events along the rift systems. Tectonophysics. 124, 193-209, 1986.

Dvorak. J. J., F. W. Klein. and D. A. Swanson. Relaxation of the south flank after the 7 magnitude Kalapana earthquake, Kilauea volcano, Hawaii, Bull. Seismol. Soc. Am., 84, 133-141, 1994.

Eissler, H. K and H. Kanamori, A single-force model for the 1975 Kalapana, Hawaii, earthq̨uake, J. Geophys. Res.. 92, 4827-4836, 1987

Furumoto, A. S., and R. L. Kovach. The Kalapana earth quake of November 29, 1975: An intra-plate earthquake and its relation to geothermal processes, Phys. Earth Planet. Inter., 18, 197-208, 1979.

Geist. E. L., Local tsunami and earthquake source parameters, $A d v$. Geophys. in press, 1997.

Got, J.-L.. J. Frechet, and F. W. Klein, Deep fault plane geometry inferred from muttiplet relative relocation beneath the south flank of Kilauea, J. Geophys. Res., 99, 15,375-15,386, 1994.

Hatori. T., Wave source of the Hawaii tsunamis in 1975 and the tsunami behavior in Japan (in Japanese), Zisin. 2, 355-363, 1976.

Hill, D. P., and J. J. Zucca, Geophysical constraints on the structure of Kilauea and Mauna Loa volcanoes and some implications for seismomagmatic processes, in Volcanism in Hawaii, vol. 2, edited by 
R. W. Decker, T. L. Wright, and P. H. Stauffer, U.S. Geol. Surv. Prof. Pap., 1350, 903-917, 1987.

Hwang. L.-S., D. Divoky, and A. Yuen, Amchitka tsunami study, Rep. TC-177, 84 pp., Pasadena, Calif., Tetra Tech. Inc.. 1970

Hwang, L.-S., H. L. Butler. and D. Divoky, Tsunami model: Generation and open-sea characteristics. Bull. Seismol. Soc. Am., 62, 1579-1596. 1972a.

Hwang. L.-S.. H. L. Butler, and D. Divoky, Tsunami generation and propagation, paper presented at 13th International Conference on Coastal Engineering, Vancouver, B. C., Can.. July 10-14, 1972b.

Imamura, F.. N. Shuto, S. Ide, Y. Yoshida, and K. Abe, Estimate of the tsunami source of the 1992 Nicaraguan earthquake from isunami data, Geophys. Res. Lett., 20, 1515-1518, 1993.

Imamura. F.. E. Gica, T. Takahashi, and N Shuto, Numerical simulation of the 1992 Flores tsunami. interpretation of tsunami phenomena in northeastern Flores island and damage at Babi island. Pure Appl. Geophys. 144, 555-568, 1995.

Johnson, J. M, and K. Satake. The 1965 Rat islands earthquake: A critical comparison of seismic and tsunami wave inversions. Bull. Seismol. Soc. Am. 86, 1229-1237, 1996.

Johnson, J. M. and K. Satake, Estimation of seismic moment and slip distribution of the April 1, 1946, Aleutian tsunami earthquake, $J$. Geophys. Res., 102, 11,765-11,774. 1997.

Johnson, J. M., K. Satake, S. R. Holdahi, and J. Sauber, The 1964 Prince-William-Sound earthquake: Joint inversion of tsunami and geodetic data, J. Geophys. Res., 101. 523-532, 1996.

Kajiura, K., Tsunami source, energy, and the directivity of wave radiation, Bull. Earthquake Res. Inst. Univ. Tokyo, 48, 835-869, 1970

Kawakatsu, H., Centroid single-force inversion of seismic waves generated by landslides, J. Geophys. Res. 94. 12.363-12,374, 1989.

Lamb. H., Hydrodynamics, 738 pp., Cambridge Univ. Press, New York. 1932.

Lipman, P.W. J. P. Lockwood, R. T. Okamura, D. A. Swanson, and K. M. Yamashita. Ground deformation associated with the 1975 magnitude-7.2 earthquake and resulting changes in activity of Kilauea volcano. Hawaii, U.S. Geol. Surv. Prof. Pap. 1276, 45, 1985.

$\mathrm{Ma}, \mathrm{K} . \mathrm{F}$. K. Satake and H. Kanamori, The origin of tsunami excited by the 1989 Loma Prieta earthquake: Faulting or slumping, Geophys. Res. Lett. 18, 637-640, 1991a.
Ma, K.-F., K. Satake, and H. Kanamori, The tsunami excited by the 1906 San Francisco earthquake, Bull. Seismol. Soc. Am., 81, 1396-1397. 199 lb.

Murty. T. S., Seismic sea waves-tsunamis, Bull. Fish. Res. Board Can., 198. 1-337, 1977

Owen, S., P. Segall, J. Freymuller, A. Miklius, R. Denlinger, T. Arnadottir, M. Sako, and R. Burgmann, Rapid deformation of the south flank of Kilauea volcano, Hawaii, Science, 267, 1328-1332, 1995.

Satake, K., Inversion of tsunami waveforms for the estimation of a fault heterogeneity: Method and numerical experiments, J. Phys. Earth, 35 , 241-254, 1987

Satake, K.. Inversion of tsunami waveforms for the estimation of heterogeneous fault motion of large submarine earthquakes: The 1968 Tokachi-oki and 1983 Japan Sea earthquakes, J. Geophys. Res., 94, $5627-5636,1989$

Swanson. D. A., W. A. Duffield. and R. S. Fiske, Displacement of the south flank of Kilauea volcano: The result of forceful intrusion of magma into the ritt zones, U.S. Geol. Surv. Prof. Pap. 963, 39. 1976.

Tanioka. Y.. and K. Satake, Fault parameters of the 1896 Sanriku tsunami earthqquake estimated from tsunami numerical modeling, Geophys. Res. Lett. 23. 1549-1552. 1996.

Tilling. R. I.. R. Y. Koyanagi, P. W. Lipman, J. P. Lockwood, J. G. Moore, and D. A. Swanson. Earthquake and related catastrophic events, island of Hawaii. November 29. 1975: A preliminary report. U.S. Geol. Surv. Circ., 740,33, 1976.

Wyss, M. R. L. Kovach Comment on "A single force model for the 1975 Kalapana. Hawaii, earthquake" by Holly K. Eissler and Hiroo Kanamori, J. Geophys. Res., 93, 8078-8082, 1988.

H. Kanamori, Seismological Laboratory, California Institute of Technology. Pasadana. CA 91125.

K.-F. Ma. Institute of Geophysics. National Central University, Chung-Li 320-54, Taiwan. (fong@sal.gep.ncu.edu.tw)

K. Satake. Seismotectonics Section, Geological Survey of Japan. Tsukuba, Jbaraki 305. Japan.

(Received September 9, 1997; revised Februrary 16, 1999; accepted March I, 1999.) 